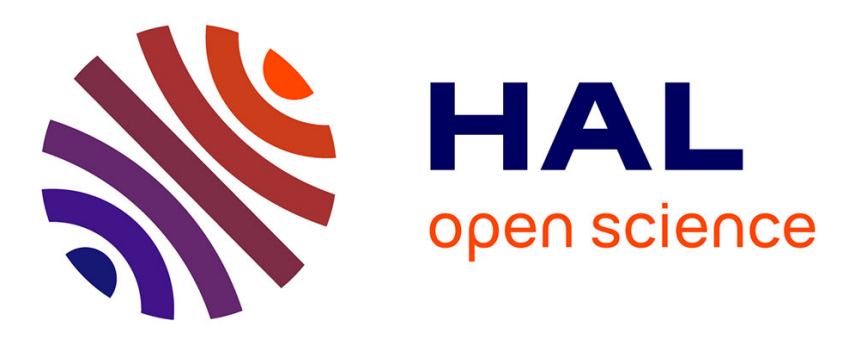

\title{
Physical modelling of sub-salt gliding due to fluid overpressure in underlying sedimentary strata
}

Dhaou Akrout, Peter R. Cobbold, Riadh Ahmadi, Eric Mercier, Mabrouk Montacer

\section{- To cite this version:}

Dhaou Akrout, Peter R. Cobbold, Riadh Ahmadi, Eric Mercier, Mabrouk Montacer. Physical modelling of sub-salt gliding due to fluid overpressure in underlying sedimentary strata. Marine and Petroleum Geology, 2016, 72, pp.139-155. 10.1016/j.marpetgeo.2016.01.019 . insu-01265373

\section{HAL Id: insu-01265373 \\ https://hal-insu.archives-ouvertes.fr/insu-01265373}

Submitted on 1 Feb 2016

HAL is a multi-disciplinary open access archive for the deposit and dissemination of scientific research documents, whether they are published or not. The documents may come from teaching and research institutions in France or abroad, or from public or private research centers.
L'archive ouverte pluridisciplinaire $\mathbf{H A L}$, est destinée au dépôt et à la diffusion de documents scientifiques de niveau recherche, publiés ou non, émanant des établissements d'enseignement et de recherche français ou étrangers, des laboratoires publics ou privés. 


\title{
Physical modelling of sub-salt gliding due to fluid overpressure in underlying sedimentary strata
}

\author{
Dhaou Akrout ${ }^{\mathrm{a}, *}$, Peter R. Cobbold ${ }^{\mathrm{b}}$, Riadh Ahmadi ${ }^{\mathrm{c}}$, Eric Mercier ${ }^{\mathrm{d}}$, \\ Mabrouk Montacer ${ }^{\mathrm{a}}$
}

${ }^{a}$ U.R : U3G - Géosystèmes, Géoressources et Géoenvironnements (UR13ES80), Faculté des Sciences de Gabès, Tunisie

${ }^{b}$ Géosciences-Rennes (UMR6118), CNRS et Université de Rennes 1, Campus de Beaulieu, 35042 Rennes Cédex, France

${ }^{c}$ Laboratoire Eau, Energie et Environnement (LR3E), E.N.I. Sfax, Tunisie

${ }^{d}$ Laboratoire de Planétologie et Géodynamique (UMR6112), Université de Nantes et CNRS, France

\begin{abstract}
The Gulf of Mexico and the offshore Campos and Santos basins of Brazil provide good examples of sub-salt detachments, by shearing in the presence of overpressure.
\end{abstract}

We have developed new physical models of such situations, including layers of ductile silicone putty, which simulated an evaporite, and fluid overpressure in porous brittle layers. We studied two configurations, in which the maximal overpressure was either beneath a single ductile layer of silicone (simulating salt), or between two such layers of silicone (simulating an evaporite sequence).

The results of our analogue modelling showed that detachment faults appeared and persisted at the bases of the ductile layers, even though some ductile deformation occurred simultaneously within these layers. For models where maximal overpressure was between two ductile layers, detachment occurred mainly at the base of the upper silicone layer.

On comparing our models with structures in the Gulf of Mexico or offshore Brazil, we find strong similarities, which lead us to suspect that detachment is indeed possible at the base of an evaporite sequence in nature. This conclusion has strong implications, not only for the understanding of petroleum systems, but also for better management of petroleum productionin sedimentary basins.

* Corresponding author. Tel: +21698994624

E-mail addresses: dhaou.akrout@yahoo.fr, peter.cobbold@univ-rennes1.fr 


\section{Introduction}

Salt basins worldwide have provided some of the most prospective hydrocarbon reserves. The best known so far are probably those in the Gulf of Mexico, where recent activity has led to a large number of discoveries, and the South Atlantic basins of offshore Brazil. However, others exist in West Africa, the North Sea, the Gulf of Suez, the Red Sea, the Persian Gulf, the Zagros Mountains of Iran and Iraq and the north Caspian area. Many such basins display overpressure at depth, in part because of the low permeability of the salt and in part because of compaction or generation of hydrocarbons.

Salt tectonics have become increasingly important for petroleum exploration, because of their role in hydrocarbon generation and accumulation. Therefore many studies have focussed on salt tectonics and especially on the shapes resulting from salt mobility (e.g. Chapple, 1978; Davis and Engelder, 1985; Butler et al., 1987; Treloar et al., 1992; Dixon and Liu, 1992; Weimer and Buffler, 1992; Cobbold et al., 1995; Letouzey et al., 1995; Sans and Vergés, 1995; McGuinness and Hossack, 1993; Akrout, 2011a). However, these studies have assumed that deformation was facilitated by the ductile behaviour of salt layers.

In contrast, more recent work on the Gulf of Mexico (e.g. Harrison and Patton, 1995; Hudec and Jackson, 2009) has indicated that salt layers have slid over other sedimentary strata, by detaching close to their bases. Furthermore, this area has become of importance for hydrocarbon exploration. Seismic profiles and oil wells have provided good evidence for detachments, at the bases of salt layers or just below them, in response to stress of gravitational or tectonic origin. Furthermore there is evidence for fluid overpressure beneath the salt, suggesting a possible link between detachment and overpressure.

So far, physical modelling of salt tectonics has involved silicone putty as a ductile layer (for example, Cobbold et al., 1989; Cobbold and Szatmari, 1991; Vendeville and Jackson, 1992; Koyi, 1997; Ge et al., 1997; McClay et al., 1998; Gaullier et al., 2000; Brun and Fort, 2004; Fort et al., 2004; Gaullier and Vendeville, 2005; Vendeville, 2005). Independently of that, new techniques involving pore fluids in porous brittle sands have been developed at Géosciences-Rennes (Cobbold and Castro, 1999; Cobbold et al., 2001; Mourgues and Cobbold, 2003; 2006a; 2006b; Zanella et al., 2014). One of the objectives has been to study the role of overpressure in creating detachment levels (e.g. Cobbold et al., 2004). 
In this paper, we describe some new modelling of the effects of fluid pressure on detachment, especially beneath ductile layers (Akrout, 2011b). Thus we have studied 4 configurations, in which detachment occurred, either within ductile silicone, or as a result of overpressure within sand (Fig. 1). In the presence of silicone layers, maximal overpressure was initially beneath a single one of them or between two such layers (Fig. 2).

The objectives and the results are somewhat comparable to those in a recent publication on numerical (finite element) modelling of sub-salt detachments, resulting from overpressure (Luo et al., 2015). However, our physical models are more variable and more three-dimensional.

\section{Natural examples of salt detachments}

\subsection{Gulf of Mexico (Figures 3, 4, 5)}

The Gulf of Mexico (Fig. 3) is a wide area of regional salt tectonics and also one of the most prolific hydrocarbon provinces. Gravitational gliding has been responsible for up-dip extension and down-dip shortening (Fig. 4). The most prominent normal faults are of Jurassic to Early Cretaceous age and detach in the Jurassic salt. The petroleum industry has been aware of the mobility of the salt since 1970 (Schultz-Ela and Jackson, 1993).

There is a variety of models for the emplacement of allochthonous salt in the Gulf of Mexico. All involve detailed structural analyses of the geometry, evolution and fault patterns. There are several deep-water contractional fold belts associated with salts tectonics, such as the Mississippi Fold Belt (Wu et al. 1990; Weimer and Buffler 1992), Atwater thrust belt (Peel et al., 1995) and Perdido Fold Belt.

Wu et al. (1990) and Weimer and Buffler (1992) suggested that a fold belt may have formed at the basin-ward edge of a regional detachment on the Jurassic salt. Huber (1989) considered well-documented thrust faults, occurring on the upper continental slope, which are related to allochthonous salt sheets, include the Ewing Bank thrust. Glacier Models of allochthonous salt-sheet emplacement have thrust faults, which accommodate contraction that is a response to updip extension and occurs at the toes of salt sheets (Diegel et al. 1995; McGuinness and Hossack, 1993).

Jackson and Vendeville (1993) used physical models to suggest that thrust faults form at the toes of actively extruding salt sheets. 
Harrison (1993), using three dimensional seismic interpretation and well data, suggested that oblique-slip faults along the lateral margins of salt sheets indicate that detachment coincides with the base of the salt in the Mississippi Canyon area (Fig. 5). This led Harrison and Patton (1995) to advocate a model of sub-salt detachment for other fields in the Gulf of Mexico.

Very high overpressures have appeared in many wells penetrating the base of allochthonous salt (O’Brien et al., 1993a, b; LeBlanc, 1994; O’Brien and Lerche, 1994; Harrison and Patton, 1995; House and Pritchett, 1995; Baud and Haglund, 1996; Niemann, 1997; Whitson and McFadyen, 2001; Rohleder et al., 2003; Wilson et al., 2003; Ebrom et al., 2006; Harrison et al., 2010). The overpressure may result in part from compaction of waterrich, shallow sediments, which were rapidly overridden by a thick, dense, impermeable salt sheet (Luo et al., 2015). Alternatively, the overpressure may be due in part to hydrocarbon generation within source rocks, as a result of increasing temperature. This appears to have occurred, for example, in the Haynesville Shale (Upper Jurassic) of inland Louisiana (Nunn, 2012). Whatever its cause, overpressure beneath salt appears to facilitate basal slip.

\subsection{Santos Basin, offshore Brazil (Figures 6, 7)}

The Santos Basin, offshore Brazil, has emerged as one of the most exciting exploration prospects in recent years. The discovery of the Tupi field in November 2007 confirmed the potential of a pre-salt play. Since then, new pre-salt discoveries have followed in quick succession (Fig. 6): Sugarloaf in December 2007, Jupiter and Iara in 2008, and Azulao and Iracema in 2009 (Haquet, 2012). As in the Gulf of Mexico, so in the Santos Basin, detachment of an evaporitic sequence has resulted in near-shore extensional structures and distant compressional structures (Jackson et al., 2015). The evaporite sequence consists of several layers of different composition, including, not only halite, but also anhydrite (Fig. 7).

\section{Physical models}

Our sandbox modelling was done in the Laboratory of Experimental Tectonics at Géosciences-Rennes (Rennes University, France). In what follows, we shall describe the experimental procedure and materials, followed by the results of the modelling.

\subsection{Model materials}


As in previous experimental work at Géosciences-Rennes (Faugère and Brun, 1984; Davy and Cobbold, 1988; Krantz, 1991; Tron and Brun, 1991, Mourgues and Cobbold, 2003; Rodrigues et al, 2009), we used (1) sand, consisting of well-rounded quartz grains, to simulate brittle sedimentary rocks and (2) silicone putty, to simulate ductile salt. Sand has long been recognized as an appropriate analogue material for simulating the Mohr-Coulomb behaviour of natural rock multilayers, undergoing brittle deformation at shallow crustal levels (Davy and Cobbold, 1991).

For our modelling, we used Fontainebleau sand, which has negligible cohesion, an angle of internal friction of about $30^{\circ}$ and a density of approximately $1400 \mathrm{~kg} \mathrm{~m}^{-3}$. In one such sand (Sand 1), the grains were relatively coarse $(0.8 \mathrm{~mm})$, whereas in the other (Sand 3$)$ they were finer $(0.4 \mathrm{~mm})$. Ductile layers were of a quasi-newtonian silicone putty (GS1R gum of Rhône-Poulenc), having a viscosity of $10^{4} \mathrm{~Pa}$ s at $20^{\circ} \mathrm{C}$ and a density of about $1270 \mathrm{~kg} \mathrm{~m}^{-3}$.

\subsection{Apparatus (Figure 8)}

Pore fluids may modify the effective stresses in a solid framework. Hubbert introduced the concept of fluid overpressure into tectonics, so as to explain large overthrusts (Hubbert and Rubey, 1959). However, there is no record that he ever used pore fluids in sandbox models. Possibly the first to do so were Cobbold and Castro (1999), Cobbold et al. (2001) and Mourgues and Cobbold (2003).

For studies of deformation with fluid pressure, Mourgues (2003) built a simple rectangular box, $20 \mathrm{~cm}$ wide, $30 \mathrm{~cm}$ long and $10 \mathrm{~cm}$ high. The source of overpressure was beneath the model, not within it. As a result, the overpressure increased linearly with depth and Darcy flow occurred within the model.

For our experiments, we used a wider rectangular box (Fig. 8), $1 \mathrm{~m}$ x $1 \mathrm{~m}$ wide (Rodrigues et al., 2009). An electric stepper motor is able to push a mobile sidewall at a constant velocity, via screw jacks. The model is $18 \mathrm{~cm}$ thick, at most. Thus the box is sufficiently wide to ensure that a large part of the model escapes any boundary effects (friction or rigidity). The sidewalls of the apparatus are of transparent Plexiglas. Underlying the box is a flow diffuser, consisting of 400 contiguous and vertical aluminium tubes, $30 \mathrm{~cm}$ long and $5 \mathrm{~cm}$ square (Fig. 9). A highly permeable metallic mesh separates the tubes from an underlying reservoir, which provides fluid at uniform pressure. Sand in the tubes acts as a buffer, regulating fluid flow between reservoir and model. The metallic mesh prevents the sand from falling into the reservoir. The tubes channel the flow vertically and the columns of 
sand render the flow rate more uniform. The box can take either compressed air or water as a pore fluid.

To make pressure measurements inside the model, we used narrow probes, which were round tubes of aluminium, $40 \mathrm{~cm}$ long and $2 \mathrm{~mm}$ in diameter. The probes protruded horizontally through the sidewalls of the box. Their outer ends connected to U-tubes, containing water. Rather than risk deforming the model, we chose to put the probes in place first, and then to build the model around them. To prevent sand in the model from blocking the probes, we covered their inner ends with pieces of fine metallic mesh. A flow regulator and a pressure gauge served to control the flow of compressed air from an external source into the reservoir.

\section{Model construction (Figures 9, 10, 11)}

We built the models in several successive layers (Fig. 9). To deposit any one sand layer, we first sprinkled a fixed amount of sand from a beaker. Then we rendered its thickness uniform, by scraping the top surface flat. The scraper was a thin vertical plastic sheet. The purpose of the basal layer (Sand 3,1 cm thick) was to ensure good upwards percolation of air.

The piston velocity was $1 \mathrm{~cm} / \mathrm{h}$ in all models. This caused progressive deformation of the analogue material, forming thrust wedges. To avoid any loss of fluid pressure, we constantly refilled with sand the space that appeared behind the piston. The basal layer of Sand 1 remained beneath the advancing piston and thus underwent little or no deformation.

\subsection{Model 1 (no fluid pressure)}

This was a classical model (sand and silicone) without fluid pressure. The bottom layer was uniformly $1 \mathrm{~cm}$ thick and consisted of fine sand (Sand 3). The next layer, $3 \mathrm{~mm}$ thick, was of silicone putty. The third layer was of coarse sand (Sand 1), uniformly $1 \mathrm{~cm}$ thick (Fig. 9).

\subsection{Models 2 and 3 (with fluid pressure beneath ductile layers)}

\subsubsection{Model 2}

Model 2 consisted of $1 \mathrm{~cm}$ of Sand 3, $3 \mathrm{~mm}$ of silicone and another $1 \mathrm{~cm}$ of Sand 1 (Fig. 10). The total thickness was the same as for Model 1. 
Once the model was in place, we increased the air pressure steadily, until it approached the weight of overburden. Thus the fluid pressure at the base of the silicone layer was equivalent to $1.3 \mathrm{~cm}$ of water (Fig. 10). At that moment, the motor started to push the piston at a speed of $1 \mathrm{~cm} / \mathrm{h}$.

To follow the pattern of sliding, we deposited passive markers, consisting of straight lines of black sand, on the surface of the basal layer of white sand (Sand 3). Initially the marker lines were continuous along each layer and had a spacing of $20 \mathrm{~cm}$. Above them, the silicone layer consisted of strips, $20 \mathrm{~cm}$ wide, of alternating colours (red or transparent). Their boundaries coincided with the lines of black sand.

\subsubsection{Model 3}

Model 3 consisted of one layer of silicone (6 mm thick) and one layer of overlying sand (2 mm thick).

\subsection{Model 4 (with fluid pressure between two ductile layers)}

Model 4 consisted of two layers of silicone and one intervening layer of sand (Sand 1, Fig. 11). The method for constructing the layers was the same as in previous models, but procedures were different for obtaining overpressure in the intervening layer (Sand 1).

First, the meshes at the tops of the tubes were clogged, except for those at the side of the box, away from the piston. This allowed air to rise locally from the pressure chamber. Second, a strong metal bar ( $1 \mathrm{~cm}$ square) prevented the overpressured air from entering the basal layer (Sand 3). Instead, it could enter the intervening layer (Sand 1). Finally, we drilled a hole downwards, from the centre of the free surface of the model, as far as the intervening layer (Sand 1). We then used thin horizontal probes, connected to U-tubes, to monitor the pressure in the basal reservoir and in the sand layers.

\section{Basic experimental results}

\subsection{Model 1 (Figures 12 and 13)}

Model 1 consisted of ductile and brittle layers and was not under fluid pressure. It was initially $91 \mathrm{~cm}$ long and $1.3 \mathrm{~cm}$ thick and was then subject to $20 \mathrm{~cm}$ of piston displacement. The object was to compare it with classical models of thrust propagation above 
ductile detachments (e.g. Davis and Engelder, 1985) and our subsequent models, which were subject to fluid pressure.

The rate of piston displacement was slow $(1 \mathrm{~cm} /$ hour $)$. Photographs of the upper surface show folds, between conjugate reverse faults (Fig. 12). These amplified progressively, while new ones propagated sequentially away from the piston. After $20 \mathrm{~cm}$ of piston displacement, the compressional structures occupied no more than $10 \%$ of the free upper surface and the rest of it showed no distortion. A vertical longitudinal section (Fig. 13) showed compressional structures in the upper sand layer, in the form of pop-ups with surface slopes of as much as $36^{\circ}$, and ductile detachments within the silicone layer. The structures had become asymmetric close to the piston, but more symmetric away from it.

\subsection{Models 2 and 3 (Figures 14, 15 and 16)}

These models were subject to fluid pressure beneath ductile layers (silicone). The fluid pressure was lithostatic, equivalent to $1.3 \mathrm{~cm}$ of water. By comparison with Model 1, the deformation fronts propagated very fast, so that, after no more than $4 \mathrm{~cm}$ of piston displacement, more than 4 anticlinal structures had developed (Figs. 14 and 15).

For Model 2, after $10 \mathrm{~cm}$ of piston displacement, more than $80 \%$ of the model had deformed. Away from the piston, the wedge had propagated over a distance of about $22 \mathrm{~cm}$. At its frontal part, the free surface sloped away from the piston, at a regular angle of about $12^{\circ}$. More generally the structures were widespread and between them was a plateau of very little deformation (Fig. 14). Such a style of deformation clearly resulted from efficient basal detachment. Indeed, after $20 \mathrm{~cm}$ of piston displacement, the efficiency of the detachment was clearly visible in three dimensions (Fig. 16).

\subsection{Model 4 (Figure 17)}

For Model 4, the initial length was $95 \mathrm{~cm}$ and total thickness was $7 \mathrm{~cm}$. The fluid pressure, equivalent to a depth of $7 \mathrm{~cm}$ of water, was within a sand layer, which lay between 2 layers of silicone. Basal overpressure was equivalent to about $99 \%$ of overburden stress.

The structures at the surface were basically similar to those in the previous experiments (Models 2 and 3), which also had fluid pressure. After $20 \mathrm{~cm}$ of piston displacement, 3 pop-up structures had developed (Fig. 17).

\section{Amount of slip within the silicone layers}




\subsection{Models 2 and 3 (Figures 18, 19, 20)}

After removing the uppermost layer (Sand 1) and before cutting the silicone, we noted the positions of the black sand lines and of the boundaries between strips of silicone. Next, by comparing the initial and final positions of the coloured strips, we were able to prove that the base of the silicone had slipped over the sand (Fig. 18).

For Model 2 (Fig. 19), the first boundary between strips of silicone (T1) is visible in cross-section 1, at a distance of $13 \mathrm{~cm}$ from the final edge of the piston and therefore at $23 \mathrm{~cm}$ from the original edge of the piston, which has advanced by $10 \mathrm{~cm}$. However, the initial position (before deformation) of this first boundary was at $19 \mathrm{~cm}$ from the edge of the piston (Fig. 19, top left). Therefore we deduce that the silicone slipped through a distance of $4 \mathrm{~cm}$ at its base.

By comparison, in cross-section 2 the second transition (T2) is visible at $33 \mathrm{~cm}$ from the final position of the edge of the piston and therefore at $43 \mathrm{~cm}$ from its initial position. However, the initial position (before deformation) of this first boundary was at $39 \mathrm{~cm}$ from the edge of the piston (Fig. 19, top left). Therefore we deduce, once again, that the silicone slipped through a distance of $4 \mathrm{~cm}$ at its base.

Similarly, for Model 3 (Fig. 20), the sections show that the boundaries between strips of silicone had slipped through distances of 2.5 to $4.5 \mathrm{~cm}$ for $\mathrm{T} 1$ and 0.5 to $2.5 \mathrm{~cm}$ for T2.

\subsection{Model 4 (Figures 21, 22)}

In Model 4 the maximal overpressure was initially between the two ductile layers. Each of these was in strips of alternating colours. Thus we were able to study the patterns of slip and of internal deformation for each layer on one cross-section (Figs. 21, 22).

The upper layer of silicone, which was above the overpressured layer of sand, suffered the greatest amounts of basal slip (9.2 cm close to the piston, $2.6 \mathrm{~cm}$ furthest away, Fig. 22). This gradient in slip was responsible for horizontal shortening within the layer.

To our initial surprise, the lower layer of silicone also suffered some slip $(6.1 \mathrm{~cm}$ close to the piston, $2.0 \mathrm{~cm}$ furthest away), even though in principle there was no underlying overpressure. An explanation for this may have come from what happened to the intermediate layer of overpressured sand. In response to the advancing piston, this sand layer shortened, producing synclines and anticlines, as well as some reverse faults. Whereas the anticlines were able to lift the overburden, as well as the free surface of the model, the synclines pushed aside the underlying ductile substrate, until they touched the more resistant sand at the base of 
the model. At this moment, the overpressure would have propagated into the substrate and facilitated slip at the base of the lower silicone layer.

\section{Discussion}

\subsection{Deformation style}

The most striking result of our experimental work was how differently the deformation propagated in the first two models (Fig. 23). Indeed, the deformation front propagated much faster and further in Model 2 (which had overpressure), than it did in Model 1 (which had no overpressure). In Model 1, after $20 \mathrm{~cm}$ of piston displacement, the compressional deformation had affected no more than $10 \%$ of the model length. In contrast, for Model 1, after no more than $10 \mathrm{~cm}$ of piston displacement, the compressional deformation had affected more than $80 \%$ of the length.

The styles of compressional deformation in Model 1 and Model 2 showed some similarities and some differences. The similarities were in the pop-up styles of anticlines, between thrusts of opposite vergences. However the structures were much more symmetric in Model 2 (as a result of efficient basal slip) than they were in Model 1.

\subsection{Base-salt detachments}

For Model 2 and Model 3, by comparing the initial and final states of coloured markers, we were able to prove that the base of the silicone had slipped over the sand, as a result of overpressure. Similarly, in Model 4 the upper silicone layer slipped readily over the underling sand, which was subject to overpressure. Although the lower silicone layer was not subject to overpressure from the start, it too slipped over the underlying sand. However, we attribute this to the leakage of overpressure, when synclines in the upper sand layer touched the lower sand layer, by squeezing out the ductile silicone. Thus, in all of the models, the silicone layers slipped at their bases, as a result of overpressure.

By comparison with our models, it would seem that salt layers in the Gulf of Mexico may have slipped at their bases, rather than detaching by ductile shear (Harrison and Patton, 1995). Indeed, overpressure exists there, beneath the salt (Harrison et al., 2010). In contrast, for the Santos Basin of Brazil, there may be less evidence for strong overpressure. However, the seismic and well data would seem to indicate that the evaporites have detached strongly at 
the base (Jackson et al., 2015). Thus we suggest that further work in the Santos Basin might provide a better understanding of what has happened.

Acknowledgements. CMCU funded the PhD thesis of Dhaou Akrout. We are grateful to J.J. Kermarrec for help with laboratory apparatus.

\section{References}

Akrout, D., Ahmadi R., Mercier E., Montacer, M. 2011. Natural hydrocarbon accumulation related to formation overpressured interval; study case is the Saharan platform (Southern Tunisia). Arab J. Geosci., DOI 10.1007/s12517-011-0287-6.

Akrout, D. 2011. Caractérisation de la surpression de fluides interstitiels dans des forages pétroliers : essais de modélisation analogique et apport à l'étude des réservoirs et à l'évolution structurale et organo-sédimentaire de bassins pétroliers du Sud de la Tunisie. Thèse de doctorat, Chapter 5, p. 121-161.

Baud, R.D., Haglund, J.M. 1996. Enhanced subsalt exploration utilizing the basal salt shear model. Gulf Coast Association of Geological Societies Transactions 46, 9-14.

Baud, R.D., Haglund, J.L., Hunt, J.L., Rocque, R.L., Daigle, A.P. 2011. An emplacement model for allochthonous salt sheets with implications toward subsalt exploration.

Brun, J.P., Fort, X., 2004. Compressional salt tectonics (Angola margin). Tectonophysics 382, $129-150$.

Butler, R.W.H., Coward, H.P., Harwood, G.M., Knipe, R., 1987. Salt. Its control on thrust geometry, structural style and gravitational collapse along the Himalaya mountain front in the Salt Range of northern Pakistan. In: O’Brien, J.-J., Lerche, I. (Eds.), Dynamical Geology of Salt and Related Structures, Academic Press, London, 399-418.

Chapple, W.M., 1978. Mechanics of a thin-skinned fold-and-thrust belt. Geological Society of America Bulletin 89, 1189-1198.

Cobbold, P.R., Castro, L., 1999. Fluid pressure and effective stress in sandbox models. Tectonophysics 301, 1-19.

Cobbold, P.R., Durand, S., Mourgues, R., 2001. Sandbox modelling of thrust wedges with fluid assisted detachments. Tectonophysics 334, 245-258.

Cobbold, P.R., Mourgues, R., Boyd, K., 2004. Mechanism of thin-skinned detachment in the Amazon Fan: assessing the importance of fluid overpressure and hydrocarbon generation. Marine and Petroleum Geology 21, 1013-1025. 
Cobbold, P.R., Rossello, E., Vendeville, B., 1989. Some experiments on interacting sedimentation and deformation above salt horizons. Bulletin de la Société Géologique de France 3, 453-460.

Cobbold, P.R., Szatmari, P., 1991. Radial gravitational gliding on passive margins. Tectonophysics 188, 249-289.

Cobbold, P.R., Szatmari, P., Demercian, L.S., Coelho, D., Rossello, E.A., 1995. Seismic and experimental evidence for thin-skinned horizontal shortening by convergent radial gliding on evaporites, deep-water Santos Basin, Brazil. In: Jackson, M.P.A., Roberts, D.G., Snelson, S. (Eds.), Salt tectonics: A global perspective. American Association of Petroleum Geologists Memoir 65, 305-321.

Davis, D.M., Engelder, T., 1985. The role of salt in fold-and-thrust belts. Tectonophysics 119, $67-88$.

Davy, P., Cobbold, P.R., 1988. Indentation tectonics in nature and experiment, 1. Experiments scaled for gravity. Bull. Geol. Inst. Uppsala, N.S. 14, 129-141.

Davy, P., Cobbold, P.R., 1991. Experiments on shortening of a 4-layer model of the continental lithosphere. Tectonophysics 188, 125.

Diegel, F.A., Karlo, J.F., Schuster, D.C., Shoup, R.C., Tauvers, P.R., 1995. Cenozoic structural evolution and tectono-stratigraphic framework of the northern Gulf coast continental margin. In: Jackson, M.P.A., Roberts, D.G., Snelson, S. (Eds.), Salt tectonics: a global perspective. American Association of Petroleum Geologists Memoir 65, 109-151.

Dixon, J.M., Liu, S., 1992. Centrifuge modelling of the propagation of thrust faults. In: McClay, K.R. (Ed.), Thrust tectonics. London, Chapman and Hall, 53-69.

Ebrom, D., Albertin, M., Heppard, P., 2006. Subsalt pressure prediction from multicomponent seismics (and more!). The Leading Edge 25, 1540-1542.

Faugère, E., Brun J.P., 1984. Modélisation expérimentale de la distension continentale. Comptes-Rendus de l'Académie des Sciences, Série II 299, 365-370.

Fort, X., Brun, J.P., Chauvel, F., 2004. Salt tectonics on the Angola margin, synsedimentary deformation processes. American Association of Petroleum Geologists Bulletin 88 (11), 1523-1544.

Gaullier, V., Vendeville, B.C. 2005. Salt tectonics driven by sediment progradation: Part II Radial spreading of sedimentary lobes prograding above salt. American Association of Petroleum Geologists Bulletin 89, 1081-1089.

Gaullier, V., Mart, Y., Bellaiche, G., Mascle, J., Vendeville, B.C., Zitter, T., Benkhelil, J., Buffet, G., Droz, L., Ergun, M., Huguen, C., Kopf, A., Levy, R., Limonov, A., Shaked, 
Y., Volkonskaia, A., Woodside, J., 2000. Salt tectonics in and around the Nile Deep-sea Fan: Insights from the PRISMED II Cruise. In: Geological Society Special Publication, 111-129.

Ge, H., Jackson, M.P.A., Vendeville, B.C., 1997. Kinematics and dynamics of salt tectonics driven by progradation. Am. Assoc. Pet. Geol. Bull. 81, 398-423.

Haquet 2012. Drilling through salt. SCOR Global P\&C SE, Technical Newletter, 1-35.

Harrison H., 1993. Salt tectonics, Mississippi Canyon area, Gulf of Mexico (abs.). AAPG Hedberg Research Conference on Salt Tectonics.

Harrison, H.L., Patton, B.D., 1995. Translation of salt sheets by basal shear. In: Salt, sediment and hydrocarbons, 16th Annual Research Conference, Gulf Coast Section, SEPM Foundation, 99-107.

Harrison, J.C., Moore, D.C., Hodgkins, P., 2010. A geologic review of the Mahogany subsalt discovery: a well that proved a play. American Association of Petroleum Geologists Search and Discovery article \#60049.

House, W.M., Pritchett, J.A., 1995. Fluid migration and formation pressures associated with allochthonous salt sheets in the northern Gulf of Mexico. In: Travis, C.J., Harrison, H., Hudec, M.R., Vendeville, B.C., Peel, F.J., Perkins, B.E. (Eds.), Salt, Sediment and Hydrocarbons, 16th Annual GCSSEPM Foundation Bob F. Perkins Research Conference Proceedings 121-124.

Huber, W.F., 1989. Ewing Bank thrust fault zone Gulf of Mexico and its relationship to salt sill emplacement. $10^{\text {th }}$ Annual Research Conference, Gulf Coast Section, SEPM Foundation, 60-65.

Hudec, M.R., Jackson, M.P.A., 2006. Advance of allochthonous salt sheets in passive margins and orogens. American Association of Petroleum Geologists Bulletin 90, 1535-1564.

Hudec, M.R., Jackson, M.P.A., 2009. Interaction between spreading salt canopies and their peripheral thrust systems. Journal of Structural Geology 31, 1114-1129.

Hubbert, M.K., Rubey, W.W., 1959. Role of fluid pressure in mechanics of overthrust faulting. 1. Mechanics of fluid-filled porous solids and its application to overthrust faulting. Geological Society of America Bulletin 70, 115-166.

Jackson, C.A.-L., Jackson, M.P.A., Hudec, M.R., Rodriguez, C.R., 2015. Enigmatic structures within salt walls of the Santos Basin--Part 1: Geometry and kinematics from 3D seismic reflection and well data. Journal of Structural Geology 75, 135-162. 
Jackson, M.P.A., Vendeville, B.C. 1993. Extreme overthusting and extension above allochthonous salt sheets emplaced during experimental progradation (abs.). American Association of Petroleum Geologists Bulletin 77, 122-123.

Koyi, H., 1997. Analogue modelling: from a qualitative to an quantitative technique - a historical outline. J. Petrol. Geol. 20, 223-238.

Krantz, R.W., 1991. Measurements of friction coefficients and cohesion for faulting and fault reactivation in laboratory models using sand and sand mixtures. In: P.R. Cobbold (Ed.), Experimental and Numerical Modelling of Continental Deformation. Tectonophysics 188, 203-207.

LeBlanc, L., 1994. Drilling, completion, workover challenges in subsalt formations. Offshore $54(7), 42-59$.

Letouezey, J., Colletta, B., Vially, R., Chermette, J.C., 1995. Evolution of salt-related structures in compressional settings. In: Jackson, M.P.A., Roberts, D.G., Snelson, S. (Eds.), Salt tectonics: A global perspective. American Association of Petroleum Geologists Memoir 65, 41-60.

Luo, G., Flemings, P.B., Hudec, M.R., Nikolinakou, M.A., 2015. The role of pore fluid overpressure in the substrates of advancing salt sheets, ice glaciers, and critical-state wedges. Journal of Geophysical Research, Solid Earth 120, 87-105. doi:10.1002/2014JB011326.

McClay, K.R., Dooley, T., Lewis, G., 1998. Analog modeling of progradational delta systems. Geology 26 (9), 771-774.

McGuinness, D.B., Hossack, J.R., 1993. The development of allochthonous salt sheets as controlled by the rates of extension, sedimentation, and salt supply. $14^{\text {th }}$ Annual Research Conference, Gulf Coast Section, SEPM Foundation, 127-139.

Mourgues, R. 2003. Surpressions de fluids et décollements. PhD thesis, Université de Rennes, $258 \mathrm{pp}$.

Mourgues, R., Cobbold, P.R., 2003. Some tectonic consequences of fluid pressures and seepage forces as demonstrated by sandbox modelling. Tectonophysics 376, 75-97.

Mourgues, R., Cobbold, P.R., 2006a. Thrust wedges and fluid overpressures: Sandbox models involving pore fluids. Journal of Geophysical Research, 111, B05404, doi:10.1029/2004JB003441.

Mourgues, R., Cobbold, P.R., 2006b. Sandbox experiments on gravitational spreading and gliding in the presence of fluid overpressures. Journal of Structural Geology 28, 887-901. 
Niemann, J.C., 1997. Gulf of Mexico subsalt deformation zones; weak formation integrity rather than anomalous high pressure zones. Gulf Coast Association of Geological Societies Transactions 47, 403-411.

Nunn, J.A., 2012. Burial and thermal history of the Haynesville Shale: implications for overpressure, gas generation, and natural hydrofracture. Gulf Coast Association of Geological Societies Journal 1, 81-96.

O’Brien, J., Lerche, I., 1994. Understanding subsalt overpressure may reduce drilling risks. Oil and Gas Journal 92 (4), 28-34.

O’Brien, J.J., Lerche, I., Yu, Z., 1993a. Observations and inferences for overpressure development under salt sheets in the Gulf of Mexico. Gulf Coast Association of Geological Societies Transactions 43, 281-289.

O’Brien, J.J., Lerche, I., Yu, Z., 1993b. Measurements and models under salt sheets in the Gulf of Mexico. In: Armentrout, J.M., Bloch, R., Olson, H.C., Perkins B.F. (Eds.), Rates of Geologic Processes; Tectonics, Sedimentation, Eustasy and Climate; Implications for Hydrocarbon Exploration. 14th Annual GCSSEPM Foundation Research Conference Proceedings, 155-163.

Peel, F.J., Travis, C.J., Hossack, J.R., 1995. Genetic structural provinces and salt tectonics of the Cenozoic offshore U.S. Gulf of Mexico: a preliminary analysis. In: Jackson, M.P.A., Roberts, D.G., Snelson, S. (Eds.), Salt Tectonics: A Global Perspective. American Association of Petroleum Geologists Memoir 65, 153-175.

Rodrigues, N., Cobbold, P.R., Løseth H., 2009. Physical modelling of sand injectites. Tectonophysics 474, 610-632.

Rohleder, S.A., Sanders, W.W., Williamson, R.N., Faul, G.L., Dooley, L.B., 2003. Challenges of drilling an ultra-deep well in deepwater dSpa Prospect. SPE/IADC Drilling Conference, Amsterdam, The Netherlands, February 19-21, Paper SPE/ IADC 79810.

Sans, M., Vergés, J., 1995. Fold development related to contractional salt tectonics: Southeastern Pyrenean thrust front, Spain. In: Jackson, M.P.A., Roberts, D.G., Snelson, S. (Eds.), Salt tectonics: a global perspective. American Association of Petroleum Geologists Memoir 65, 369-378.

Schultz-Ela, D.D., Jackson, M. P. A. 1993. Evolution of extensional fault systems linked with salt diapirism modeled with finite elements. American Association of Petroleum Geologists Bulletin, 77, 179. 
Treloar, P.J., Coward, M.P., Chambers, A.F., Izatt, C.N., Jackson, K.C., 1992. Thrust geometries and rotations in the northwest Himalaya. In: McClay, K.R. (Ed.), Thrust tectonics, London, Chapman and Hall, 325-343.

Tron, V., Brun, J.-P., 1991. Experiments on oblique rifting in brittle-ductile systems. Tectonophysics 188, 71-84.

Vendeville, B.C., 2005. Salt tectonics driven by sediment progradation: part 1mechanics and kinematics. American Association of Petroleum Geologists Bulletin 89 (8), 1071-1079.

Vendeville, B.C., Jackson, M.P.A., 1992. The fall of diapirs during thin-skinned extension. Marine and Petroleum Geology 9, 354-371.

Weimer, P., Buffler, R.T., 1992. Structural geology and evolution of the Mississippi fan foldbelt, deep Gulf of Mexico. American Association of Petroleum Geologists Bulletin $76,225-251$.

Whitson, C.D., McFadyen, M.K., 2001. Lessons learned in the planning and drilling of deep, subsalt wells in the deepwater Gulf of Mexico. SPE Annual Technical Conference and Exhibition, New Orleans, LA, September 30-October 3, Paper SPE 71363.

Wilson, S.M., Edwards, S., Heppard, P.D., Li, X., Coltrin, G., Chester, D.K., Harrison, H.L., Cocales, B.W., 2003. Wellbore stability challenges in the deep water, Gulf of Mexico: case history examples from the Pompano Field. Society of Petroleum Engineers, Annual Technical Conference and Exhibition, Denver, CO, October 5-8, Paper SPE 84266.

Wu, S., Bally, A.W., Cramez, C., 1990. Allochthonous salt, structure and stratigraphy of the northeastern Gulf of Mexico: Part II - Structure. Marine and Petroleum Geology 7, 334370.

Zanella, A., Cobbold, P.R., Le Carlier de Veslud, C. 2014. Physical modelling of chemical compaction, overpressure development, hydraulic fracturing and thrust detachments in organic-rich source rock. Marine and Petroleum Geology 55, 262-274, doi: 10.1016/j.marpetgeo.2013.12.017.

\section{FIGURE CAPTIONS}

Figure 1. Four kinds of physical modelling of detachments. A. Detachments involving ductile layers (silicone). B. Fluid overpressure in purely brittle sediment (sand). C1. Maximal overpressure beneath a single ductile layer. C2. Maximal overpressure between two ductile layers. 
Figure 2. Initial pressure profiles (right) for four kinds of physical models (Models 1 to 4, left).

Figure 3. Regional map of the north-western Gulf of Mexico (modified from Diegel et al., 1995) with location of a cross section (Fig. 3).

Figure 4. Regional profile across the north-western Gulf of Mexico (Diegel et al., 1995).

Figure 5. Interpretation of seismic line in the Gulf of Mexico (Harrison and Patton, 1995), showing a basal zone of detachment (shear zone) beneath the salt.

Figures 6. Regional map of the southeast Brazilian margin, showing the pre-salt area.

Figure 7. Interpreted seismic reflection profiles in the Santos Basin, offshore Brazil. A. Seismic section showing basal detachment of salt (SCOR Global P\&C - Technical Newsletter - 2, Mai 2013). B. Time-migrated enlargement of a section (Jackson et al., 2015), illustrating changes in thickness and detachments within multilayered evaporites (layers A1 to A4). The overall sense of shear is top-to-SE. A series of faults or thin shear zones disappears at the base of the evaporites (layer A1), indicating overall detachment.

Figure 8. Apparatus (after Rodrigues et al., 2009). Longitudinal section (A) and threedimensional view (B) show plexiglass box for housing models (1), flow diffuser containing sand (2), metallic mesh (3), reservoir for compressed air (4), pressure regulator (5) and tilting table (6). Pressure probes (narrow aluminium tubes) protrude horizontally through sidewalls of box (7). Their outer ends connect to U-tubes, containing water (8).

Figure 9. A. Configuration of sand box. B. Longitudinal vertical section through Model 1, before deformation. Model consists of two layers of sand and one intervening layer of silicone.

Figure 10. Model 2. Layering (top) and pressure profile (bottom). Maximal overpressure was beneath a single ductile layer.

Figure 11. Model 4. Profiles showing layers (top) and pressure (bottom). Overpressure transmitted, from pressure chamber at base, to intermediate layer of sand (between layers of silicone), via a gap next to the endwall (right). 
Figure 12. Model 1. Photographs (oblique views of upper free surface) for 6 stages of deformation (a to f). Piston (left) advanced towards right, producing folds and thrusts.

Figure 13. Model 1. Final stage, according to oblique photograph (top), reconstructed section (middle) and reconstructed block diagrams (bottom). Deformation has propagated about half way along the model, forming high-amplitude folds and thrusts (pop-ups).

Figure 14. Model 2. Oblique photographs of upper free surface of sand, showing 6 stages (a to f) of compressional deformation, due to progressive advance of a piston (transparent plastic). Overpressure beneath a single basal layer of ductile silicone (not visible) facilitated detachment, so that compressional deformation propagated far from the piston (f).

Figure 15. Model 2. Final stage, according to oblique photograph (top) and 3D reconstruction (bottom). Compressional structures have propagated much further from the piston than in Model 1 (Fig. 12). Between the frontal box-fold (right) and the rear fold-and-thrust belt (left) is a non-deformed plateau, which has slipped at the base. The rear fold-and-thrust belt includes bands of silicone putty, which have slipped along thrust faults and facilitated basal detachment.

Figure 16. Model 3. Oblique photographs of free upper surface, showing 4 stages of progressive deformation, resulting from displacement (in cm, D) of transparent plastic piston (rear). Fluid overpressure was beneath single underlying layer of ductile silicone (not visible).

Figure 17. Model 4. Oblique photographs of free upper surface, showing 6 stages of progressive deformation, resulting from displacement (in $\mathrm{cm}, \mathrm{D}$ ) of transparent plastic piston (left). Fluid overpressure was between two underlying layers of ductile silicone (not visible).

Figure 18. Model 2. Initial position (top) and final position (bottom) of silicone layer. Oblique photographs of upper surface of silicone (left) show bands of two different colours. Plan view reconstructions (right) show positions and shapes of coloured bands, indicating their initial widths (top), or final deformed positions, shapes and boundary displacements (bottom).

Figure 19. Model 2. Vertical sections cut through basal layers and parallel to shortening direction. Diagrams (left) show 5 strips of alternating colours within silicone layer and their boundaries (T1 to T4), either before deformation (top) or after deformation (bottom). Arrows (bottom left) indicate displacements of piston or of 4 boundaries. Oblique photograph (top 
right) show positions of sections 1 and 2, after piston displacement of $\mathrm{D}=10 \mathrm{~cm}$.

Photographs of two structural profiles (T1 and T2, bottom right) show internal structures, as well as final positions of boundaries (T1 or T2) of silicone strips, at distances of 13 or $33 \mathrm{~cm}$ from piston.

Figure 20. Model 3. Vertical sections cut through basal layers and parallel to shortening direction. Diagram (top left) shows initial positions of 4 boundaries (T1 to T4) between 5 strips of alternating colours in basal silicone layer. Oblique photograph of free surface (bottom left) shows final compressional structures (folds and thrusts), as well as lines of section (1 to 5), parallel to displacement direction of piston (left). Sections (1 to 5) through basal layer of silicone (bottom right) illustrate structural styles and values indicate amounts of basal slip ( 2.5 to $4.5 \mathrm{~cm}$ for boundary $\mathrm{T} 1 ; 21$ to $23 \mathrm{~cm}$ for boundary $\mathrm{T} 2$ ).

Figure 21. Model 4. Photographs (top) and line drawing (bottom) show a single section through 3 basal layers and parallel to shortening direction. Basal layers include lowermost one of silicone, intermediate one of sand and uppermost one of silicone (with some sand sticking to its upper surface). Both silicone layers are in strips of alternating colours (red or transparent), which have visible boundaries (T1 to T4 for lower layer, T'1 to T'4 for upper layer). Line drawing of section (bottom) shows final positions of all these boundaries. Enlargement of photograph (B) shows details of compressional structures (folds and faults) within intermediate layer of sand. Final displacement of piston (right) was $24.5 \mathrm{~cm}$.

Figure 22. Model 4. Comparison between initial positions (top) and final positions (bottom) of boundaries between strips of alternating colours in lower silicone layer (Layer 1, left) or upper silicone layer (Layer 2, right). Arrows indicate values of basal detachment. Lower layer (left) has slipped less ( $6.1 \mathrm{~cm}$ close to piston, $2 \mathrm{~cm}$ away from the piston for lower layer), whereas upper layer (right) has slipped more $(9.2 \mathrm{~cm}$ close to piston, $2.6 \mathrm{~cm}$ away from piston). This difference results from the relative amounts of underlying overpressure (initially strong beneath upper layer).

Figure 23. Models 1 and 2. Comparison of structural profiles before deformation (top) or after deformation (bottom), for Model 1 (no fluid pressure, left) and Model 2 (lithostatic fluid pressure, right). Both models had the same initial layering (two sand layers and one silicone layer). This illustrates the strong effect of underlying overpressure. 


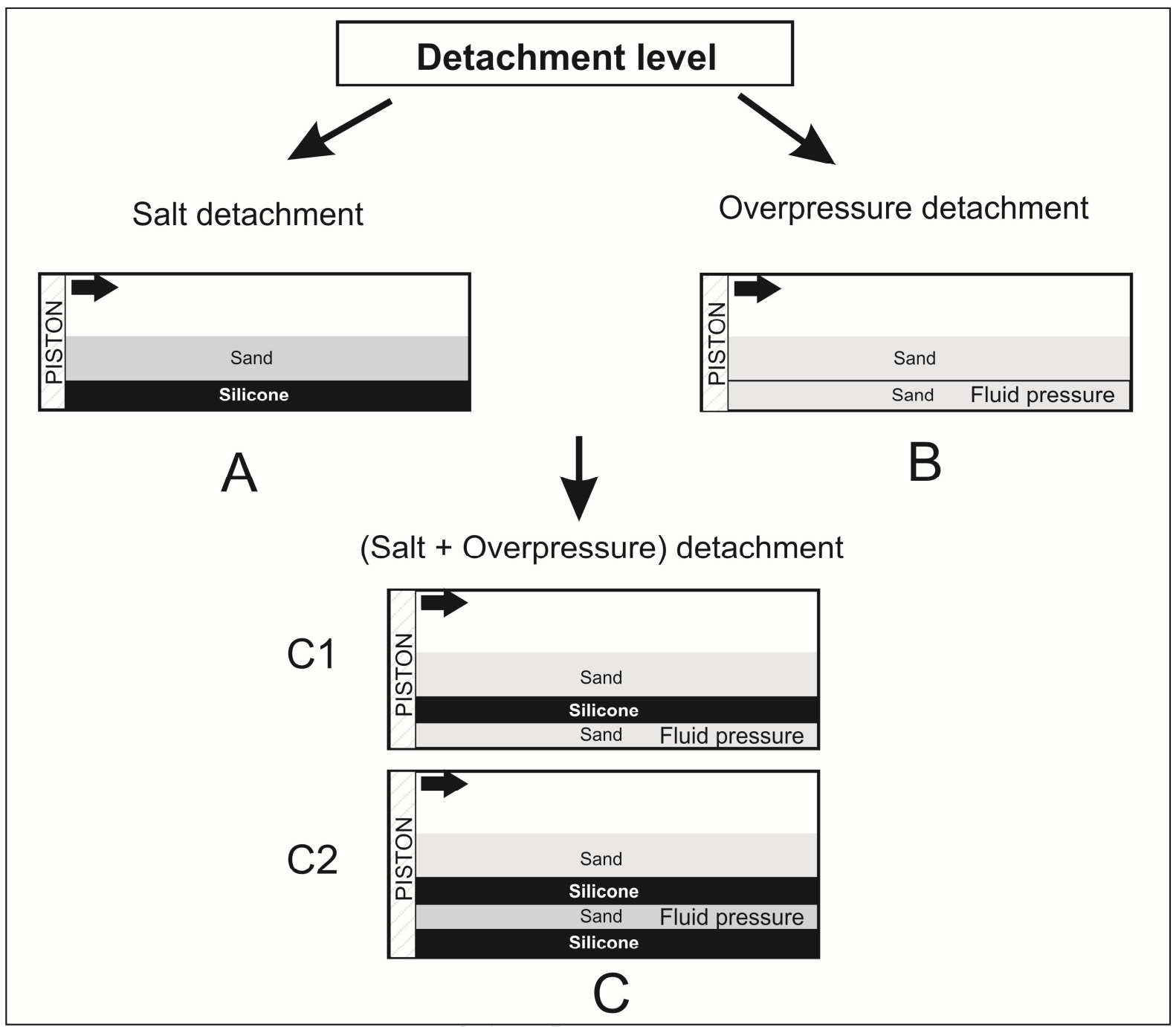




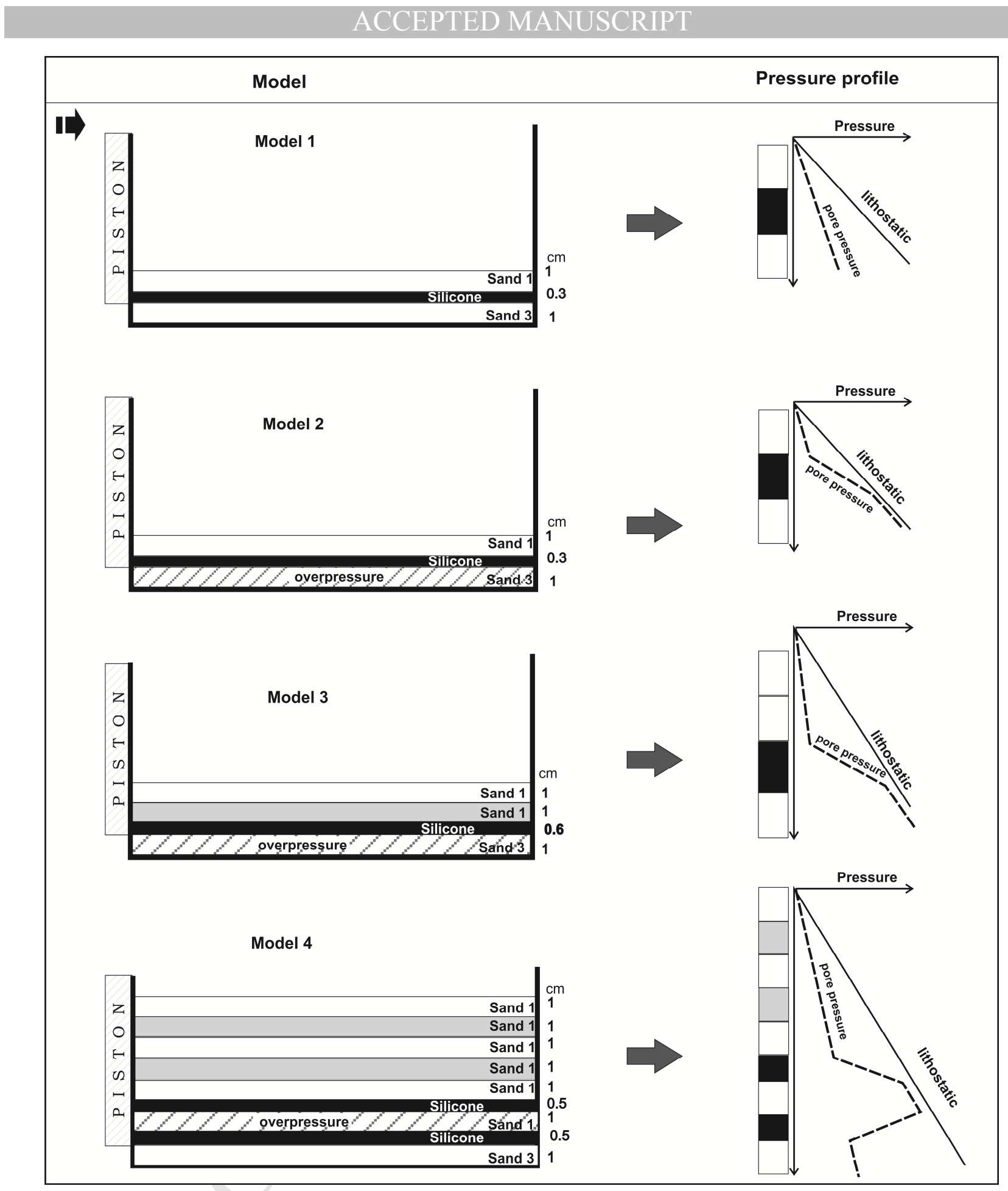


$95^{\circ} \mathrm{W}$

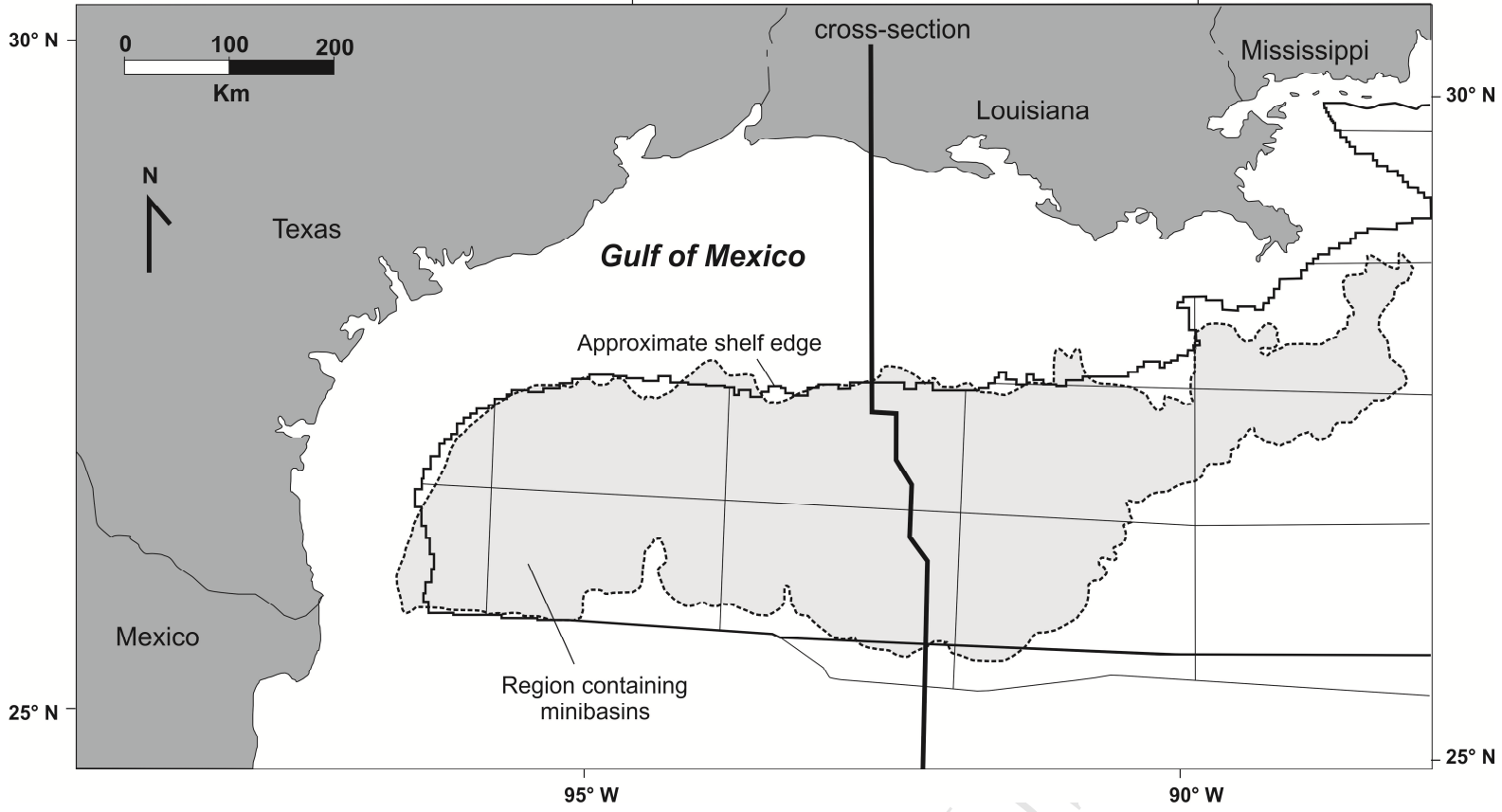


Pleistocene-Recent

S Depth $(\mathrm{Km})$

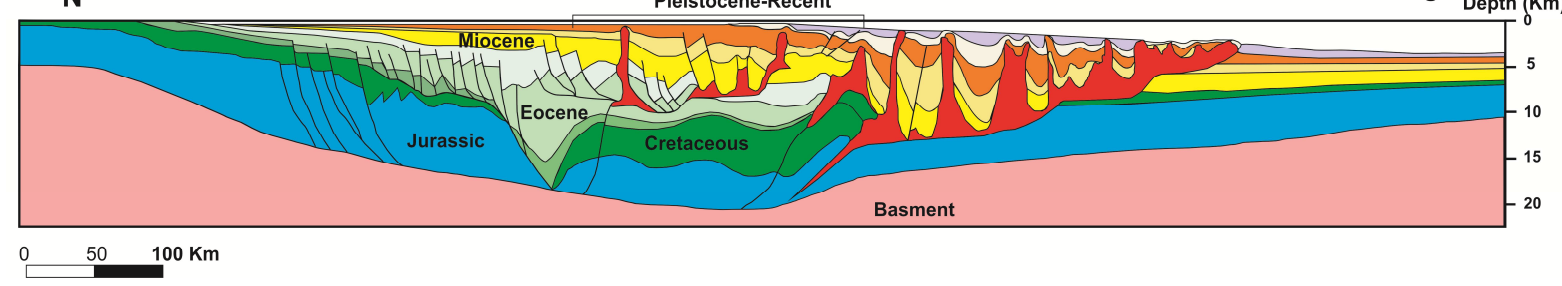




\section{ACCEPTED MANUSCRIPT}

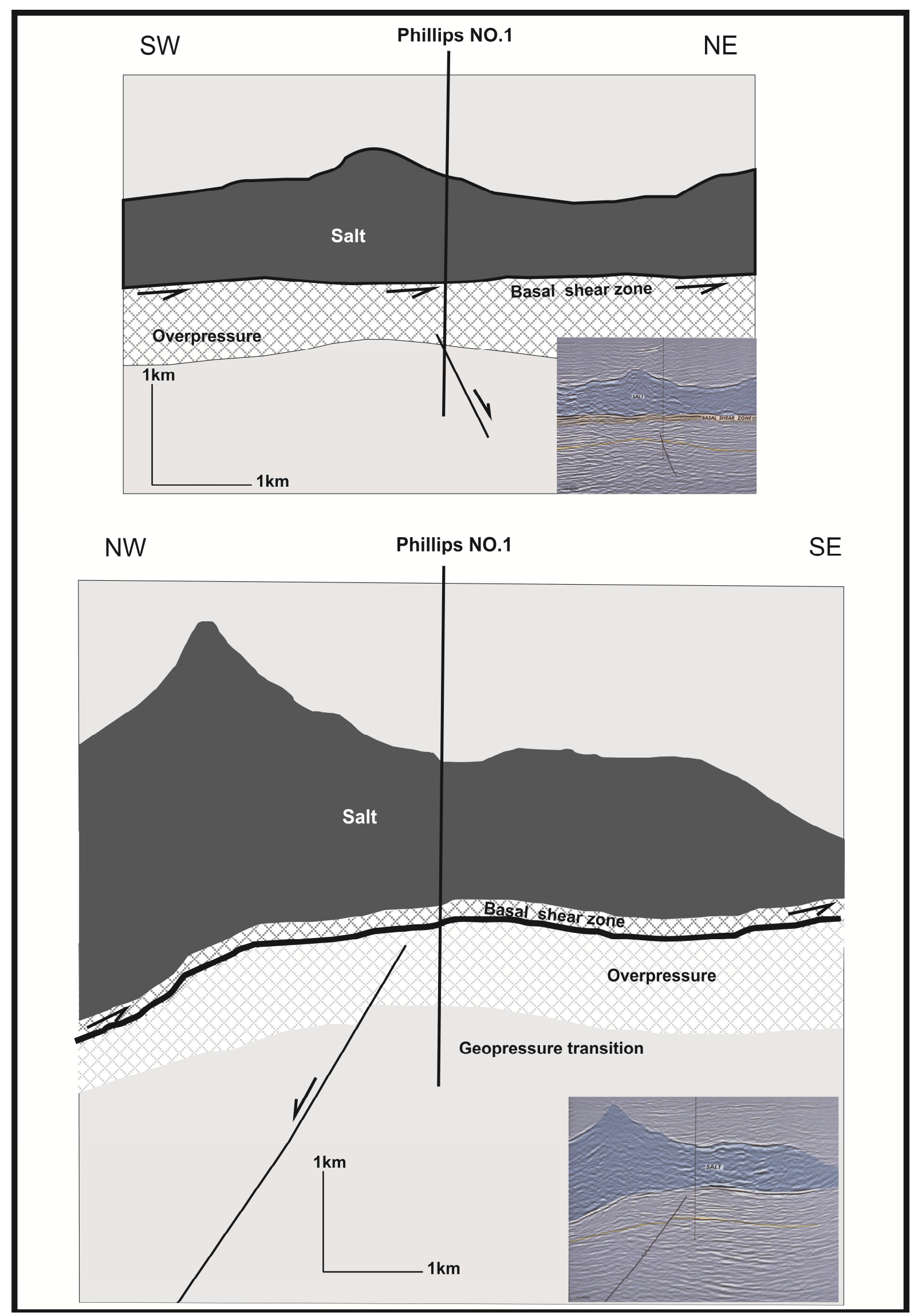




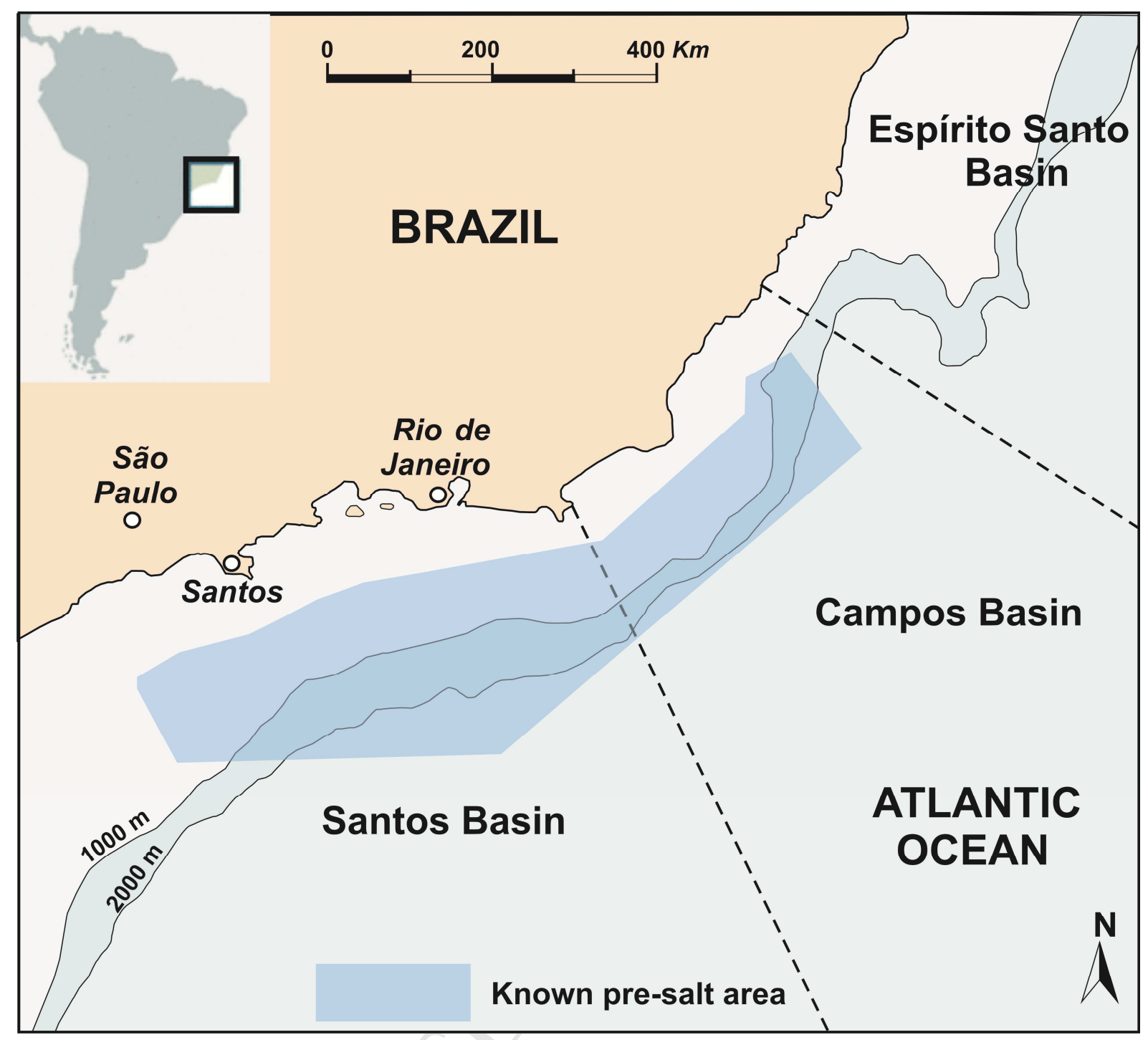




\section{ACCEPTED MANUSCRIPT}

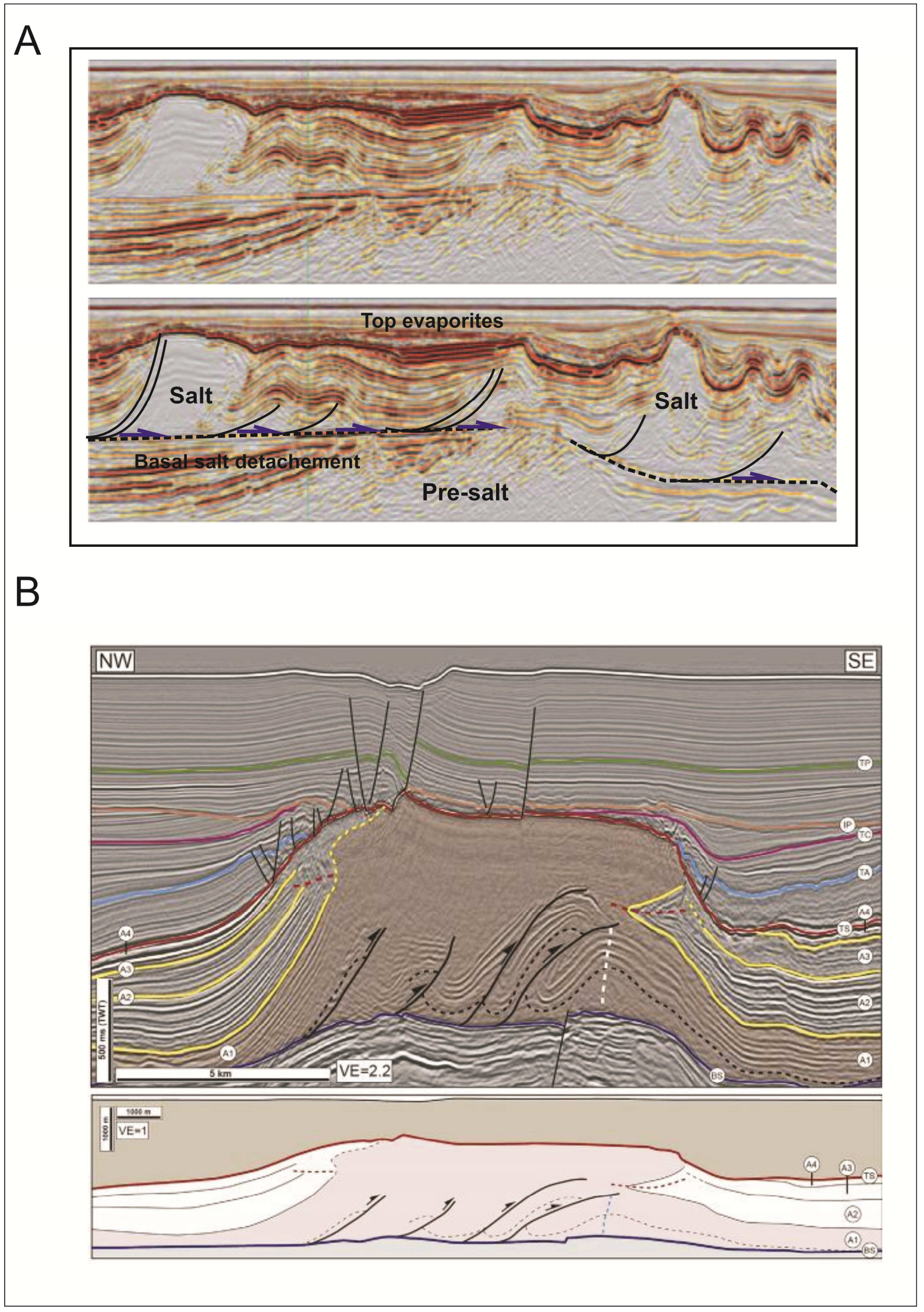



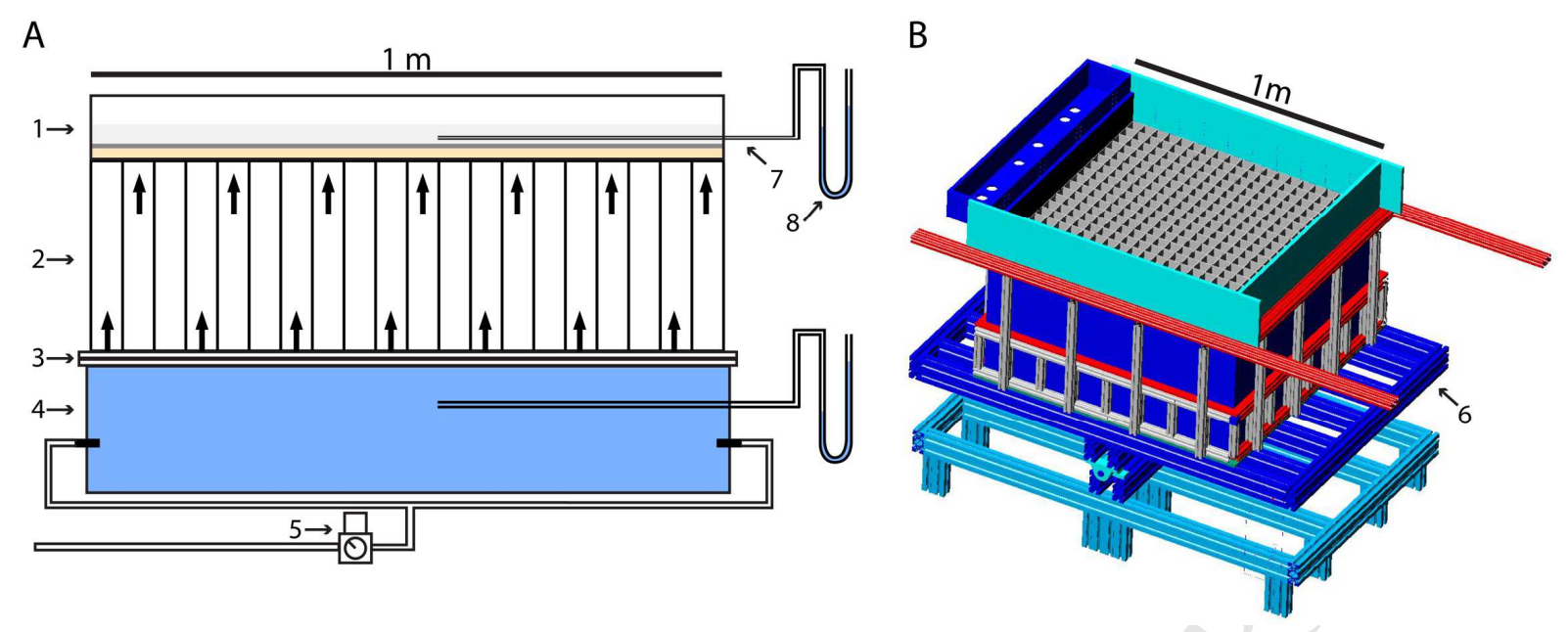
A)

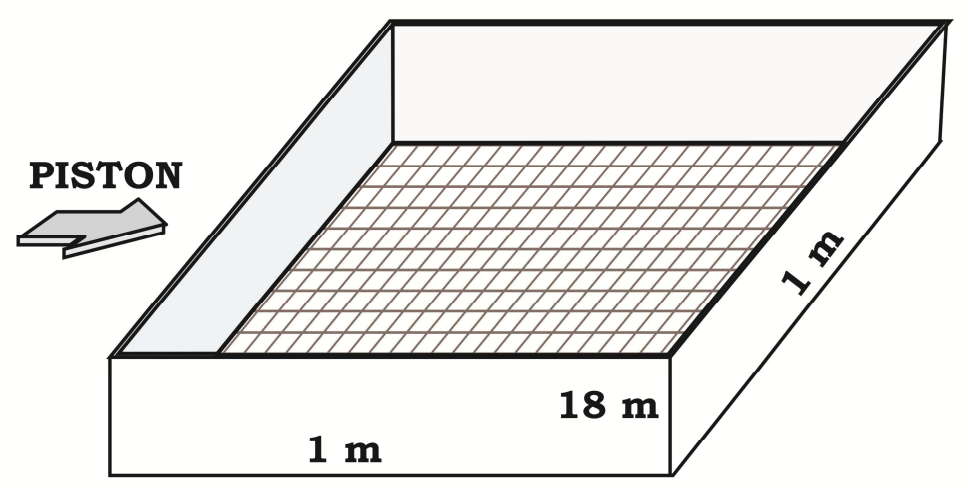

B)

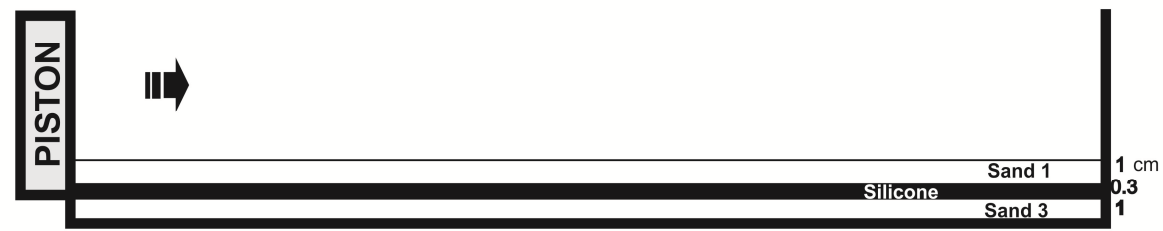



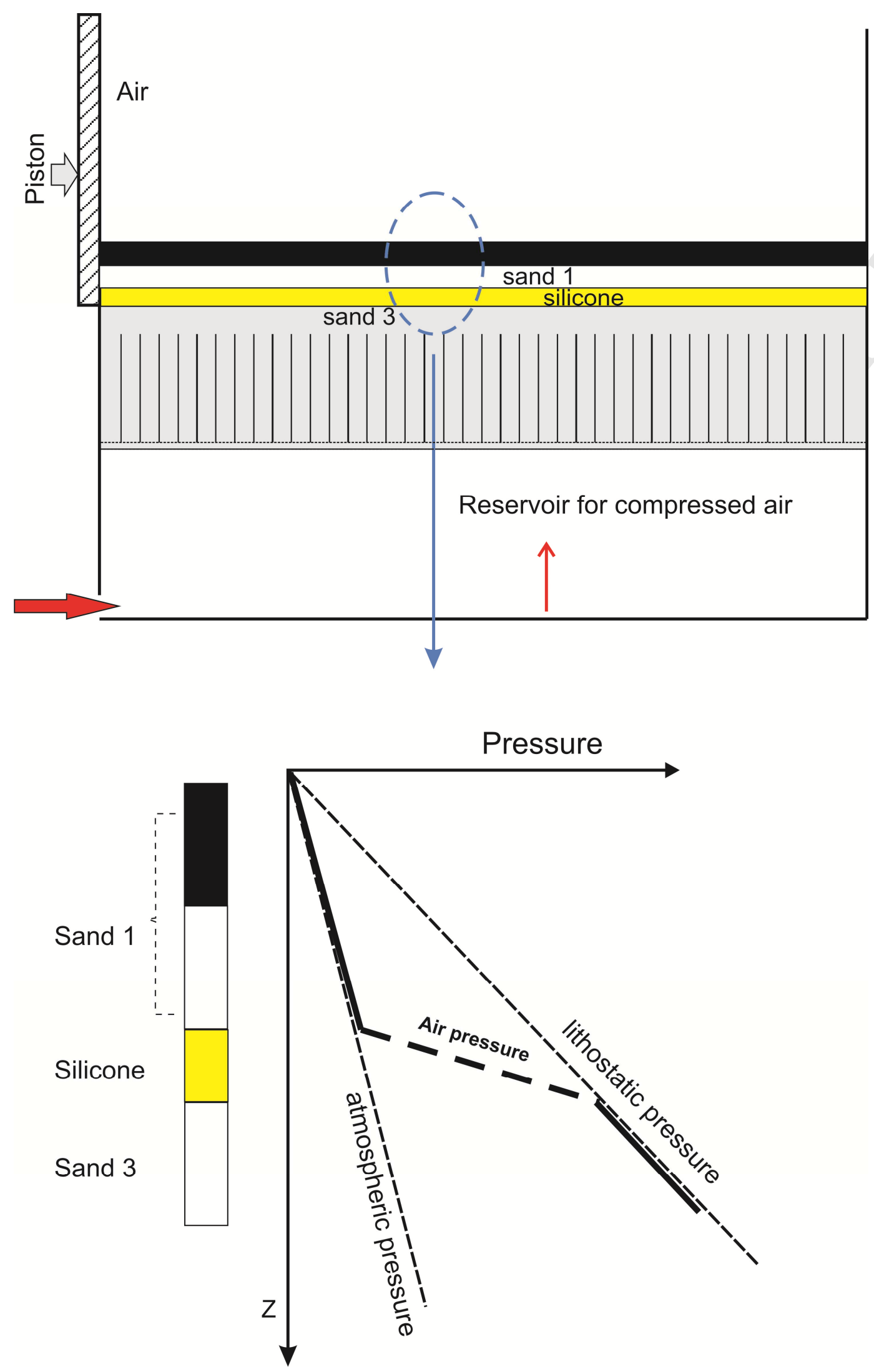


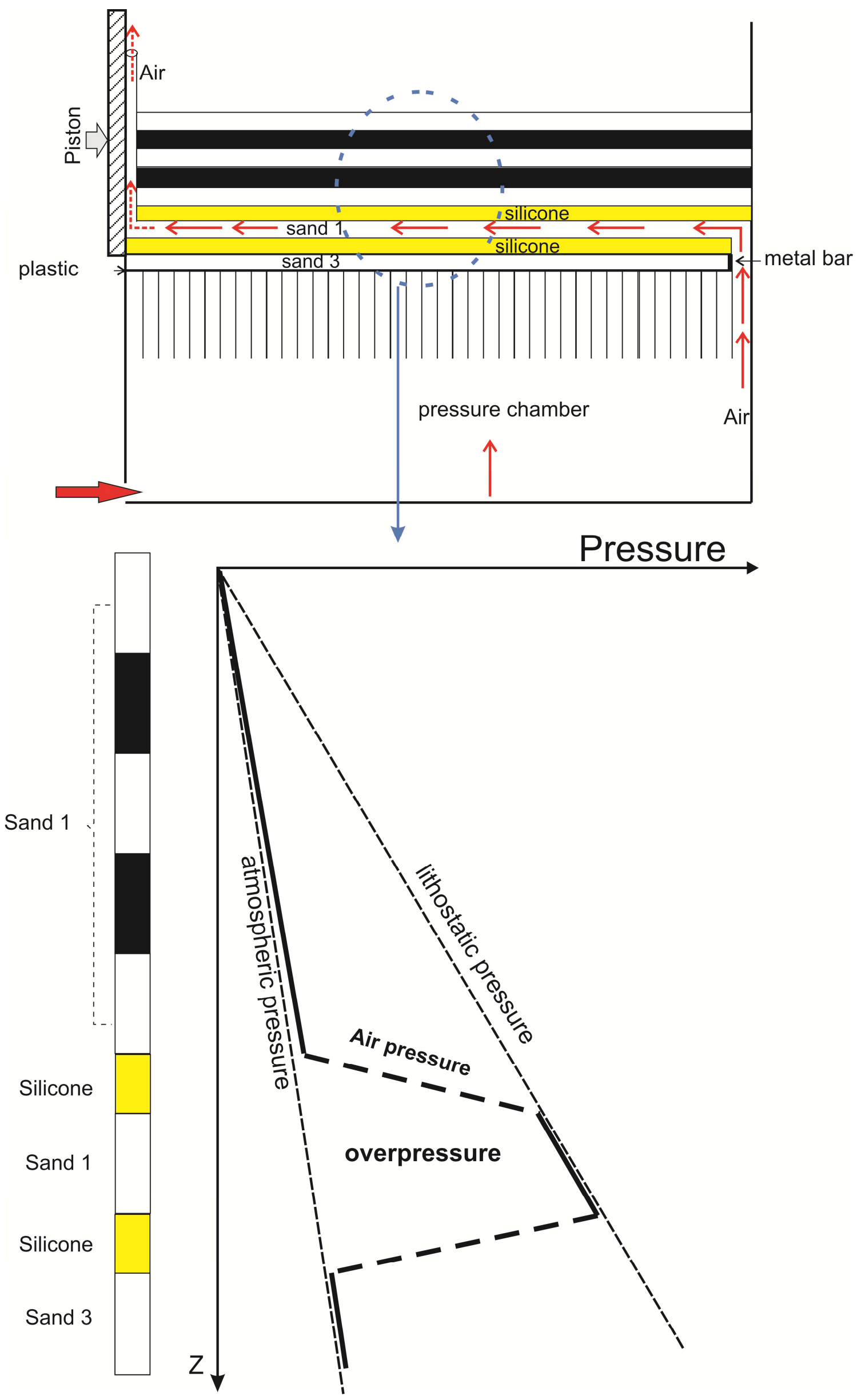




\section{ACCEPTED MANUSCRIPT}
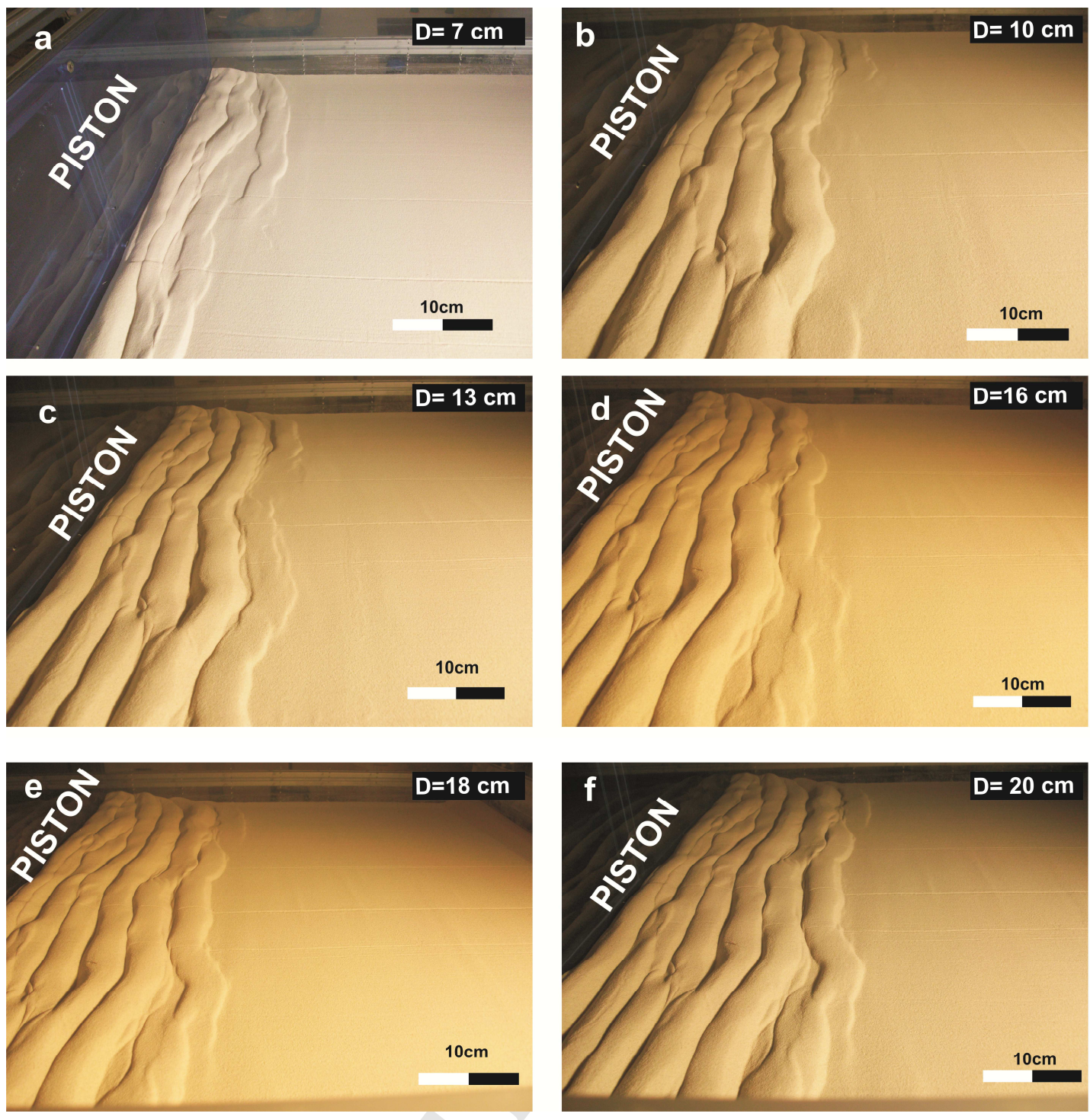


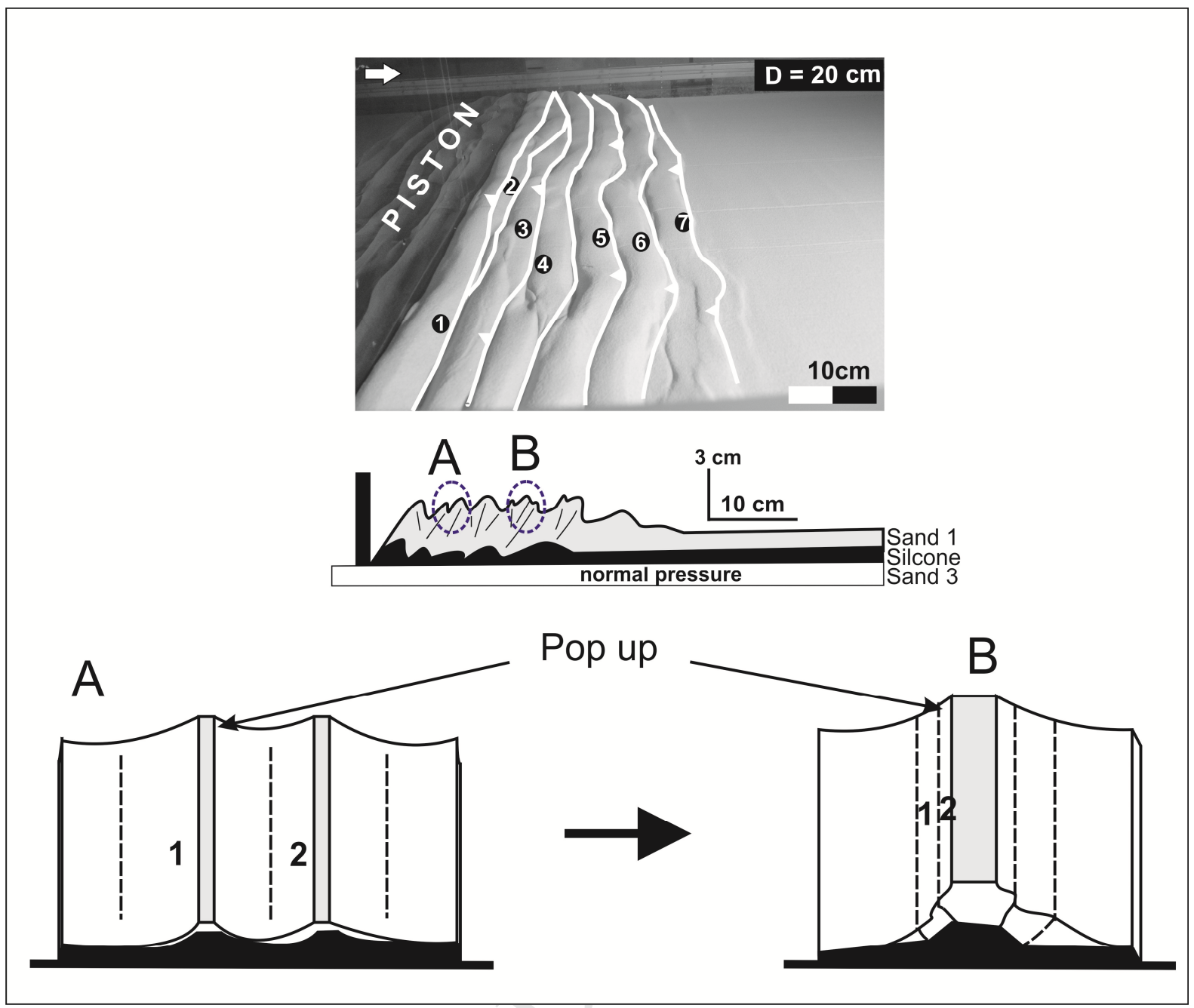




\section{ACCEPTED MANUSCRIPT}
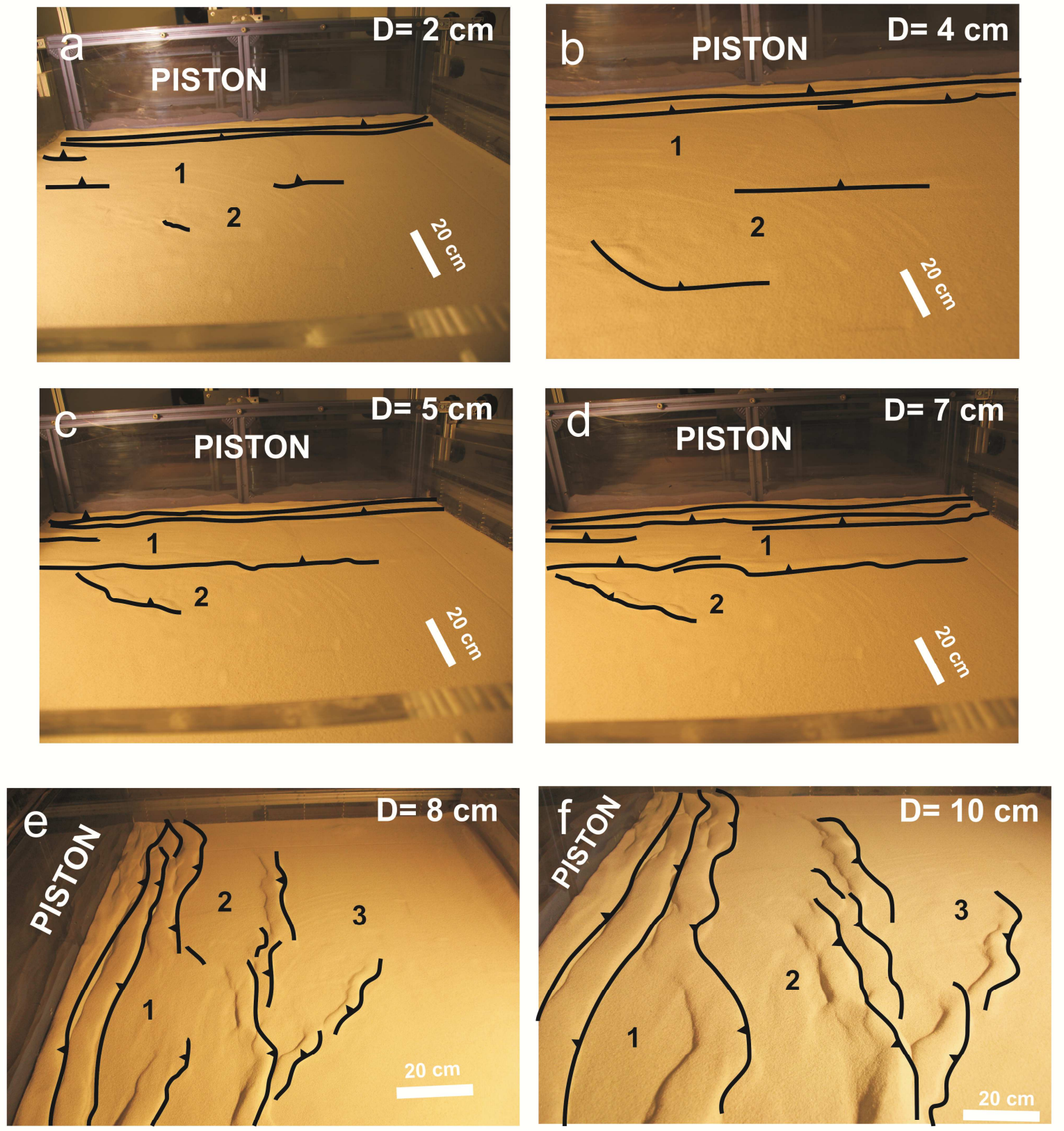


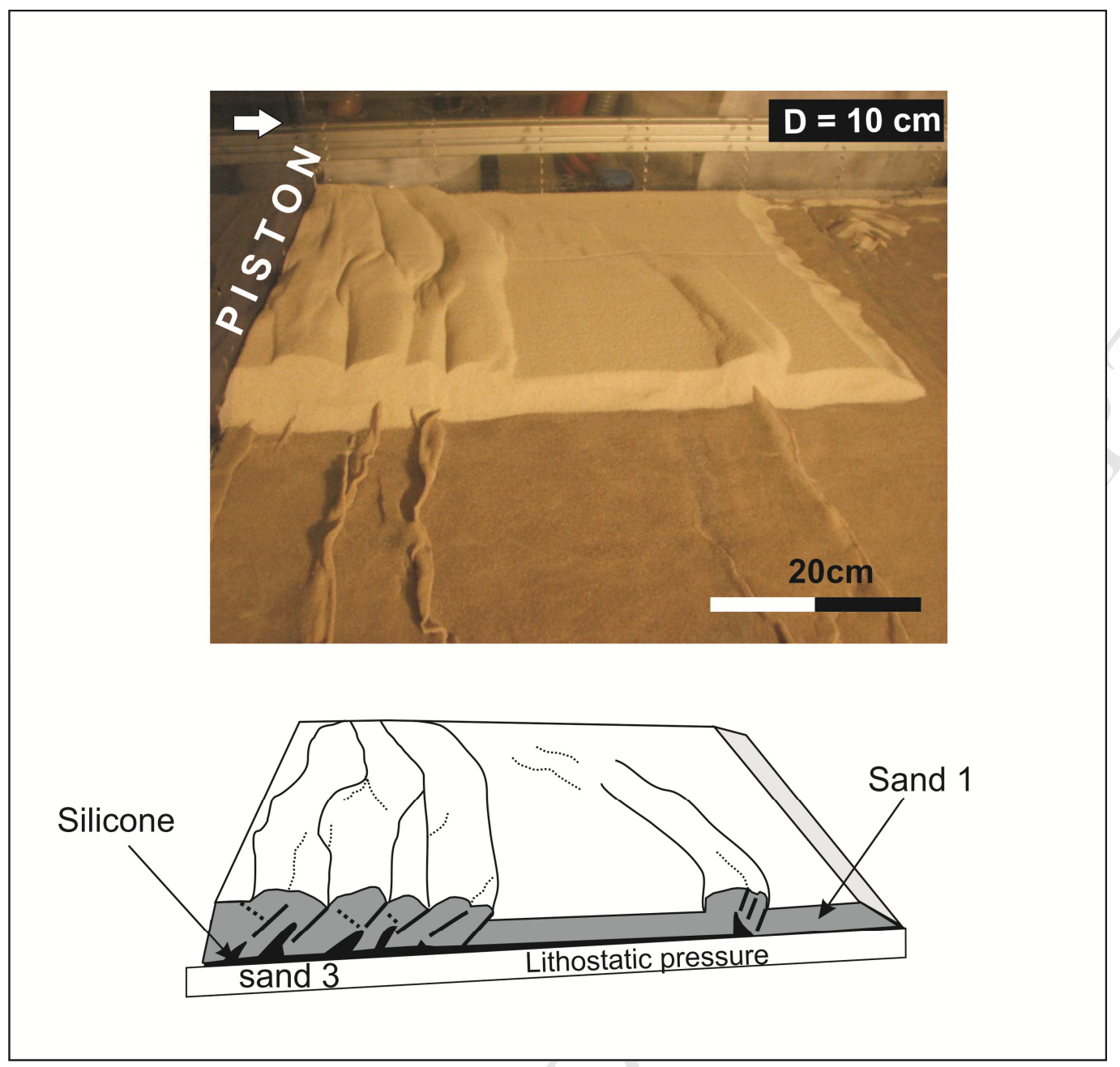




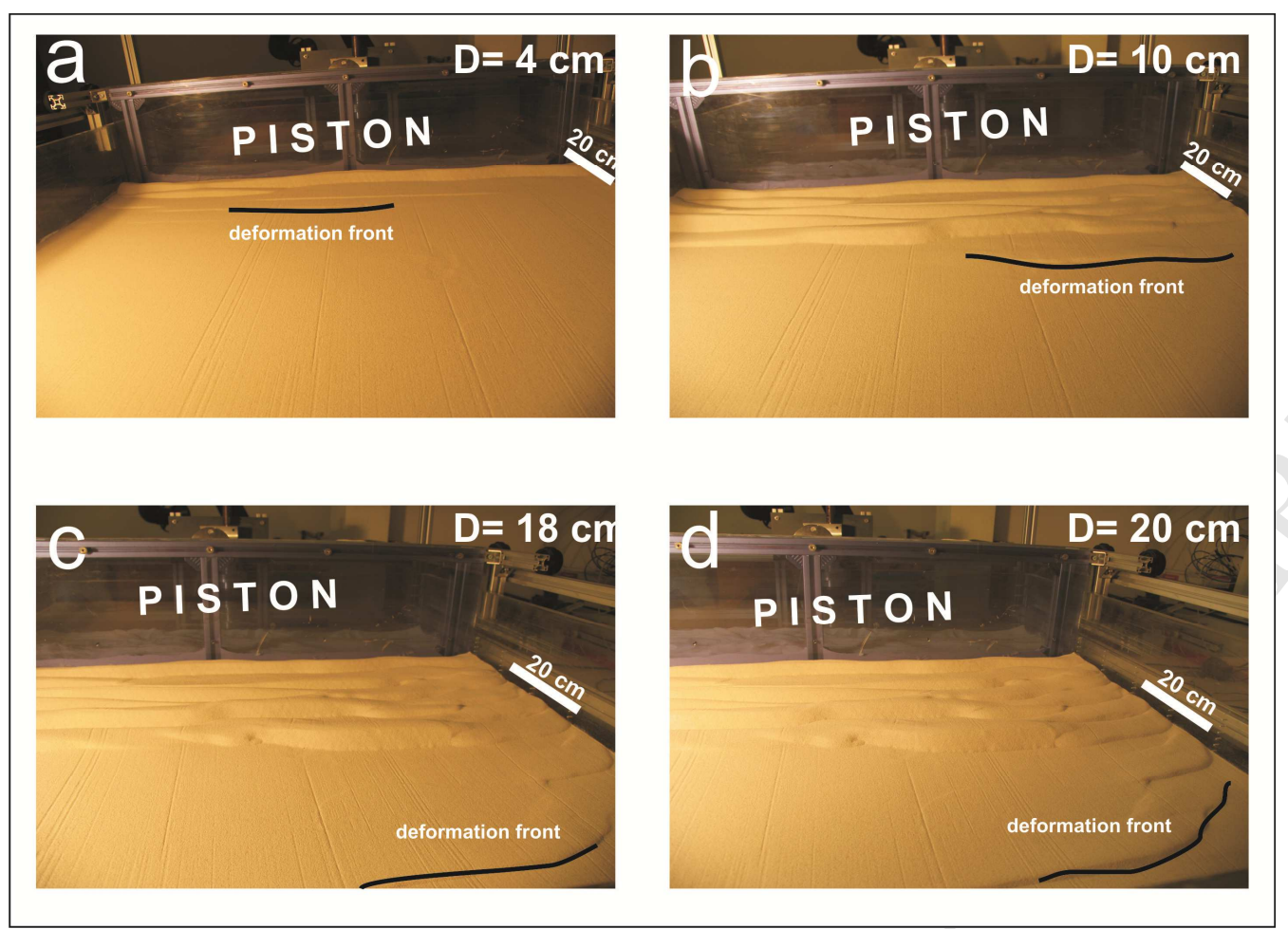




\section{ACCEPTED MANUSCRIPT}
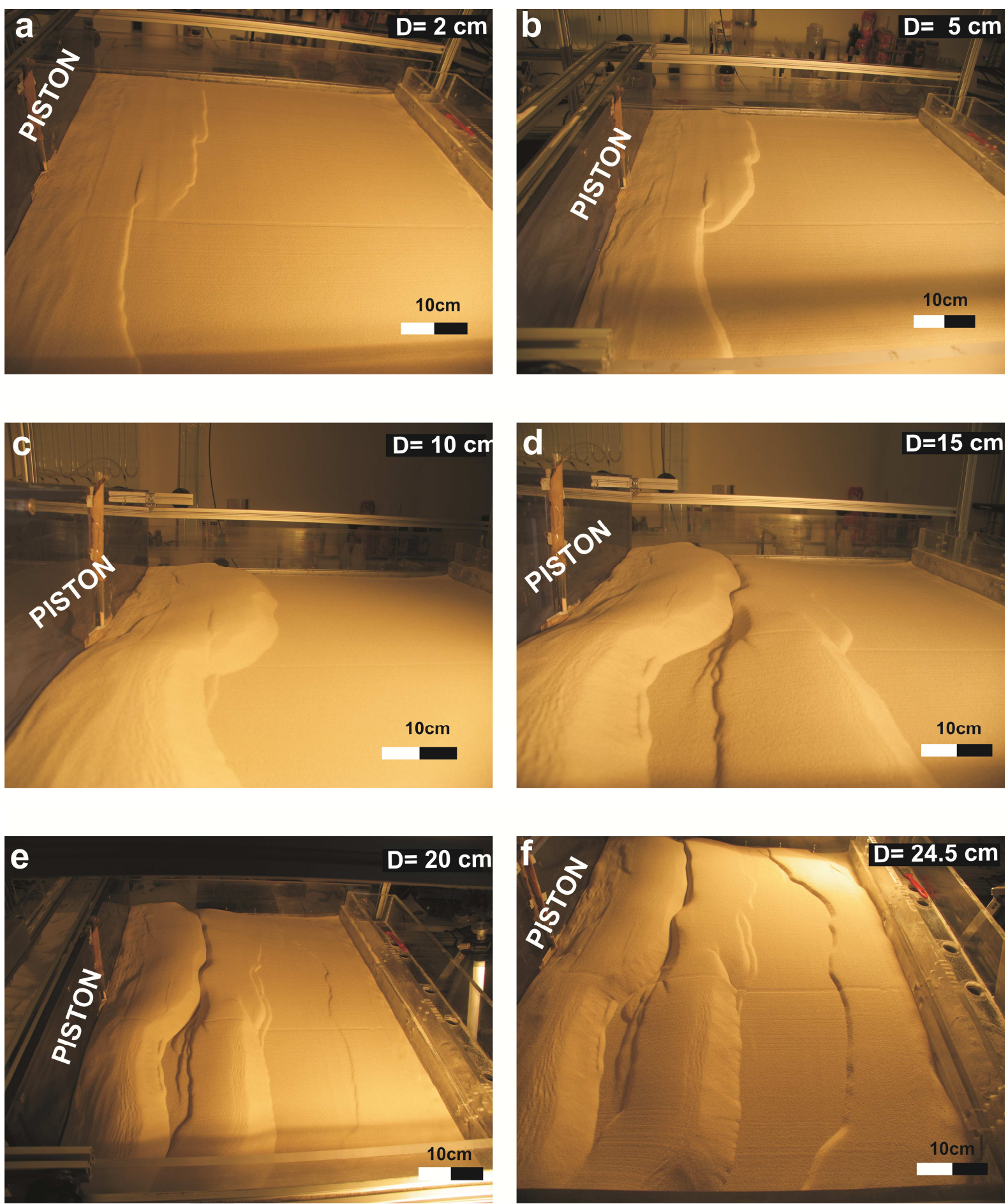


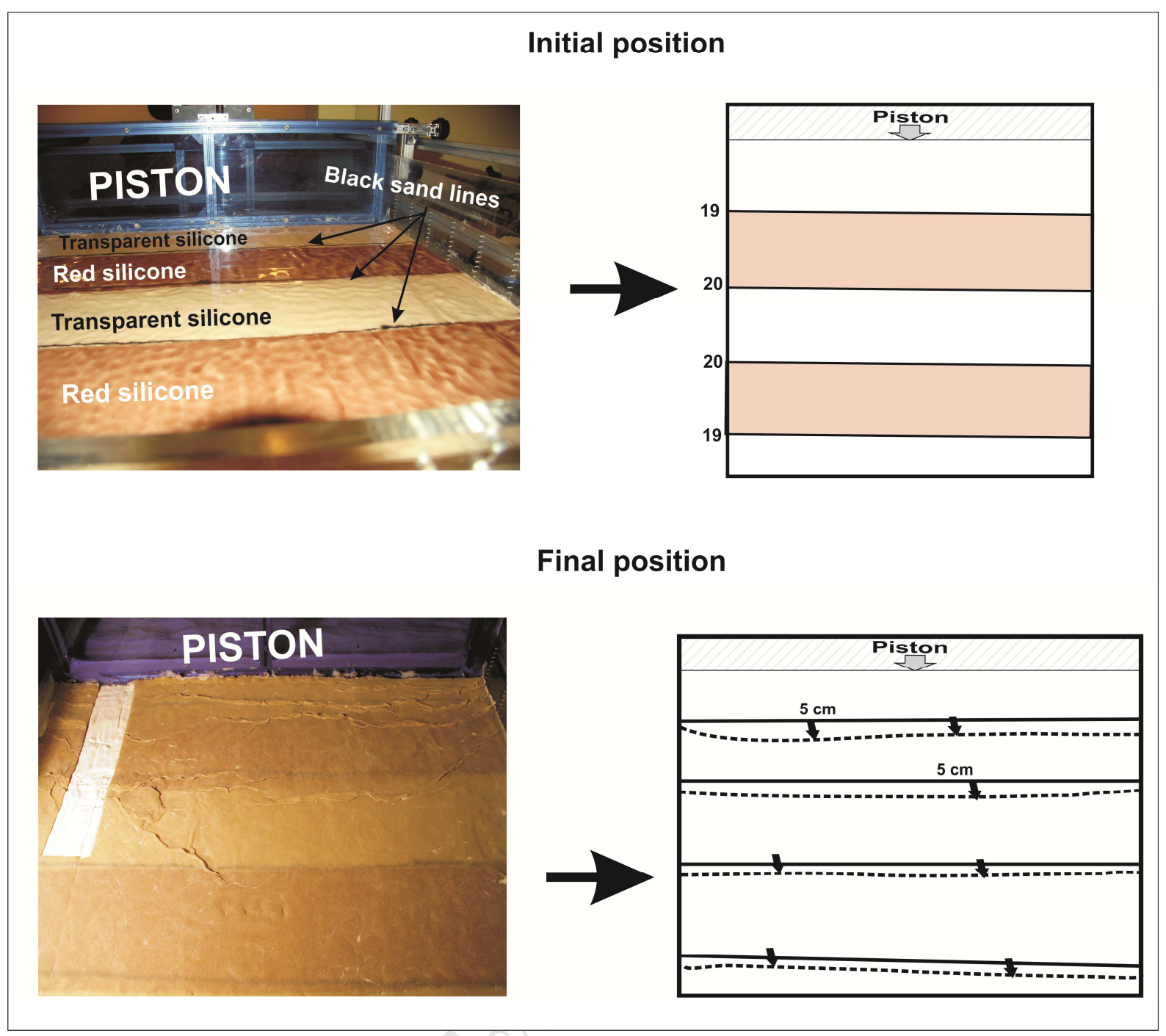




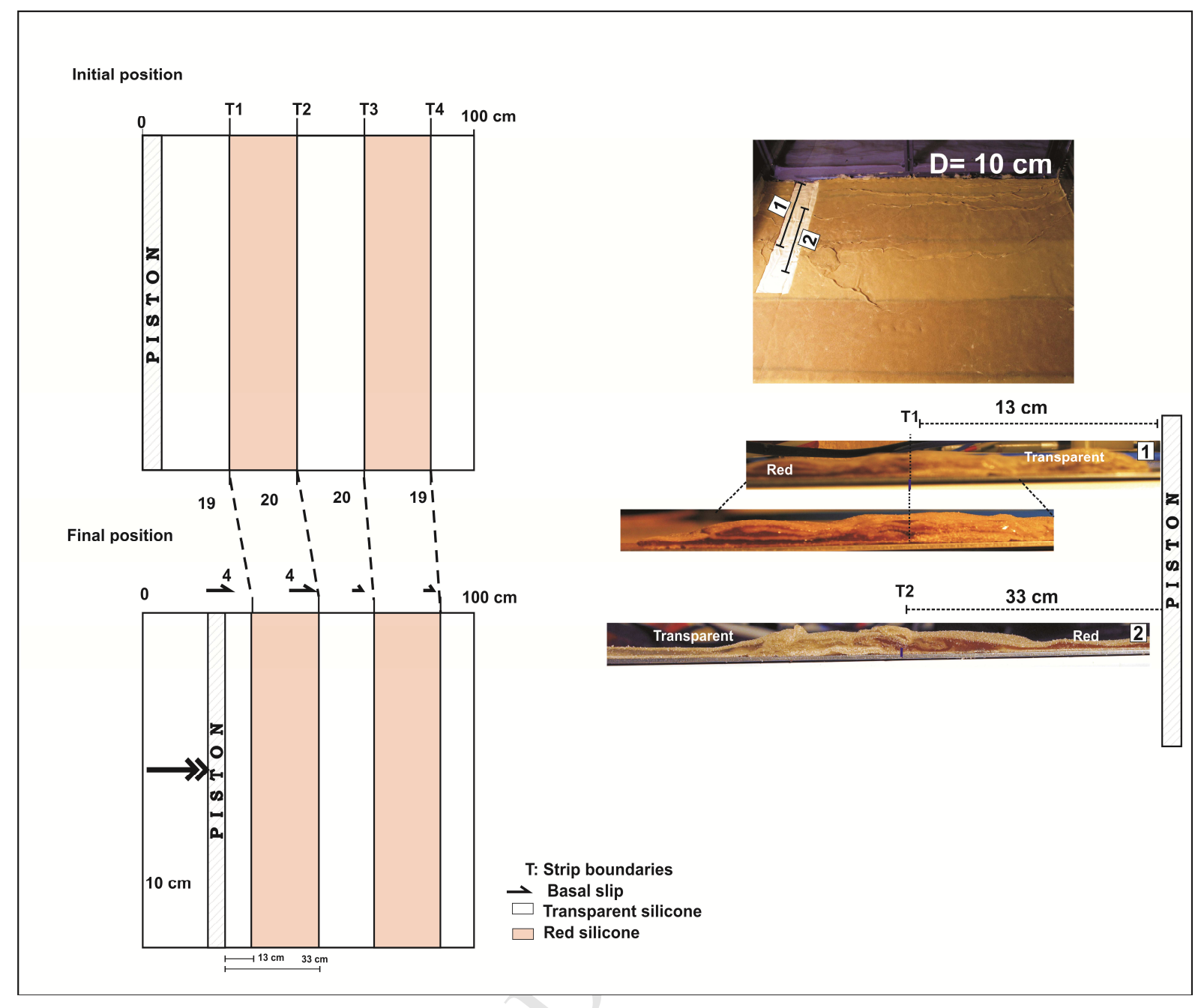


a)

Initial positions of strip boundaries
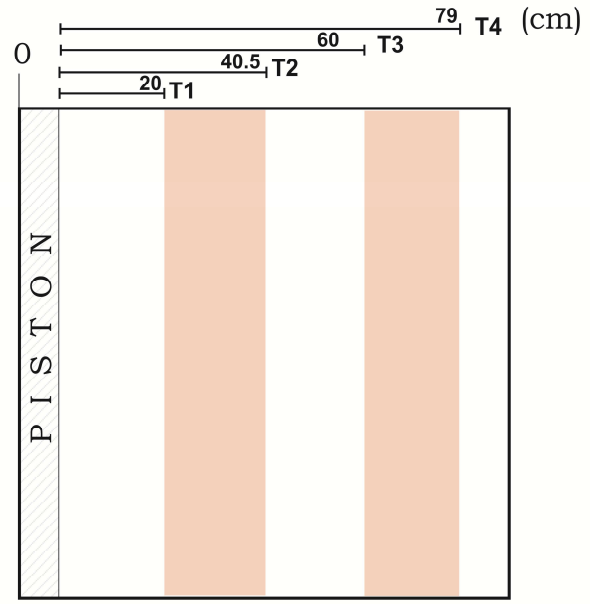

C) Section numbers

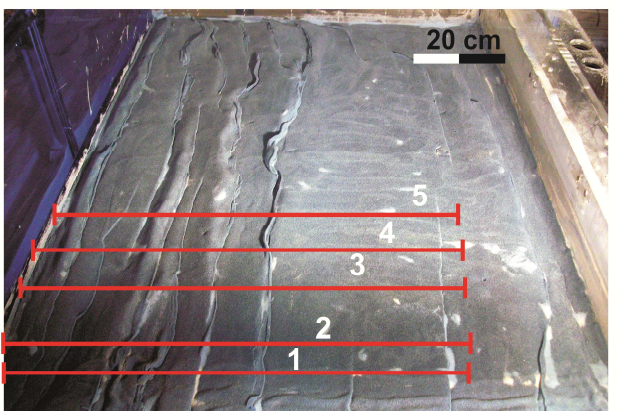

b)
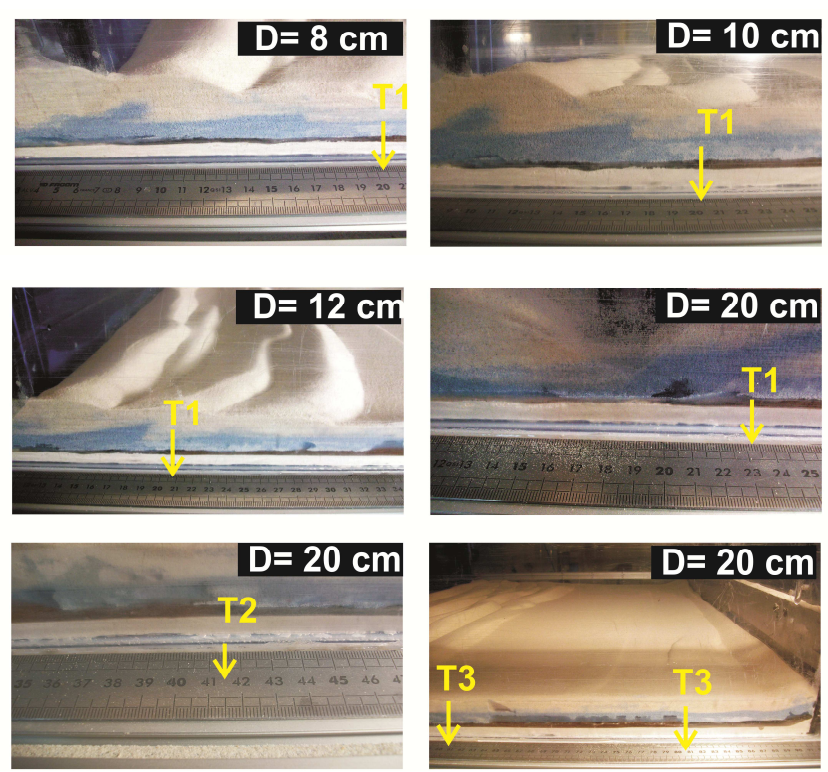

PISTON

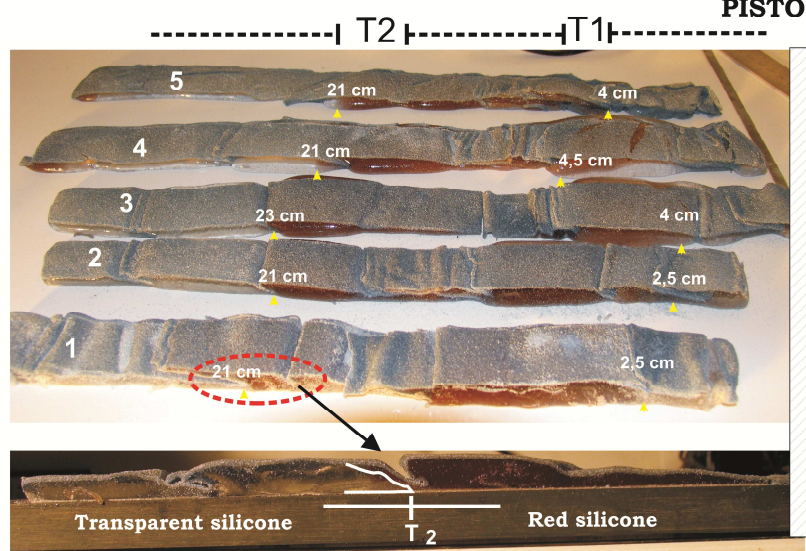




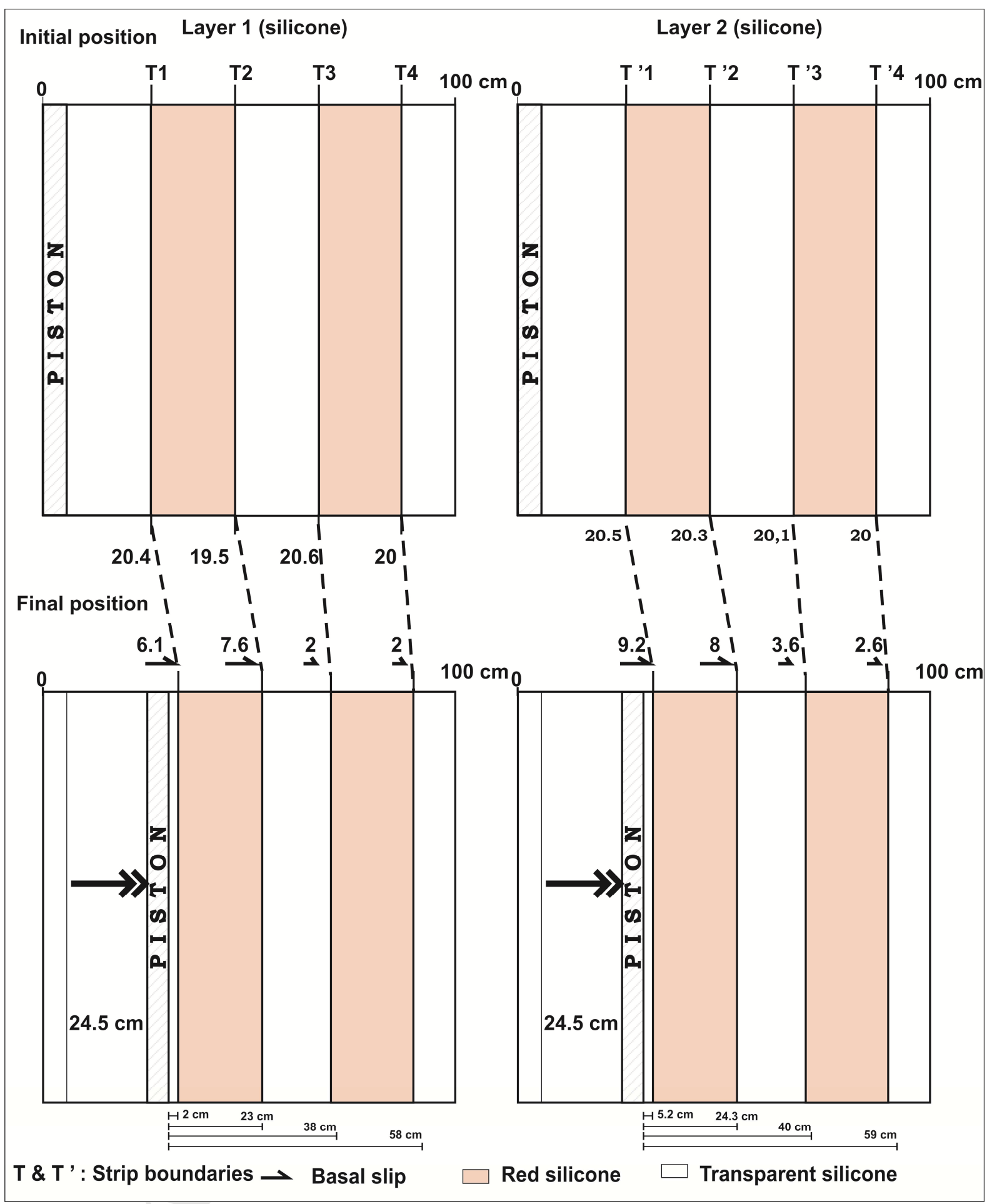



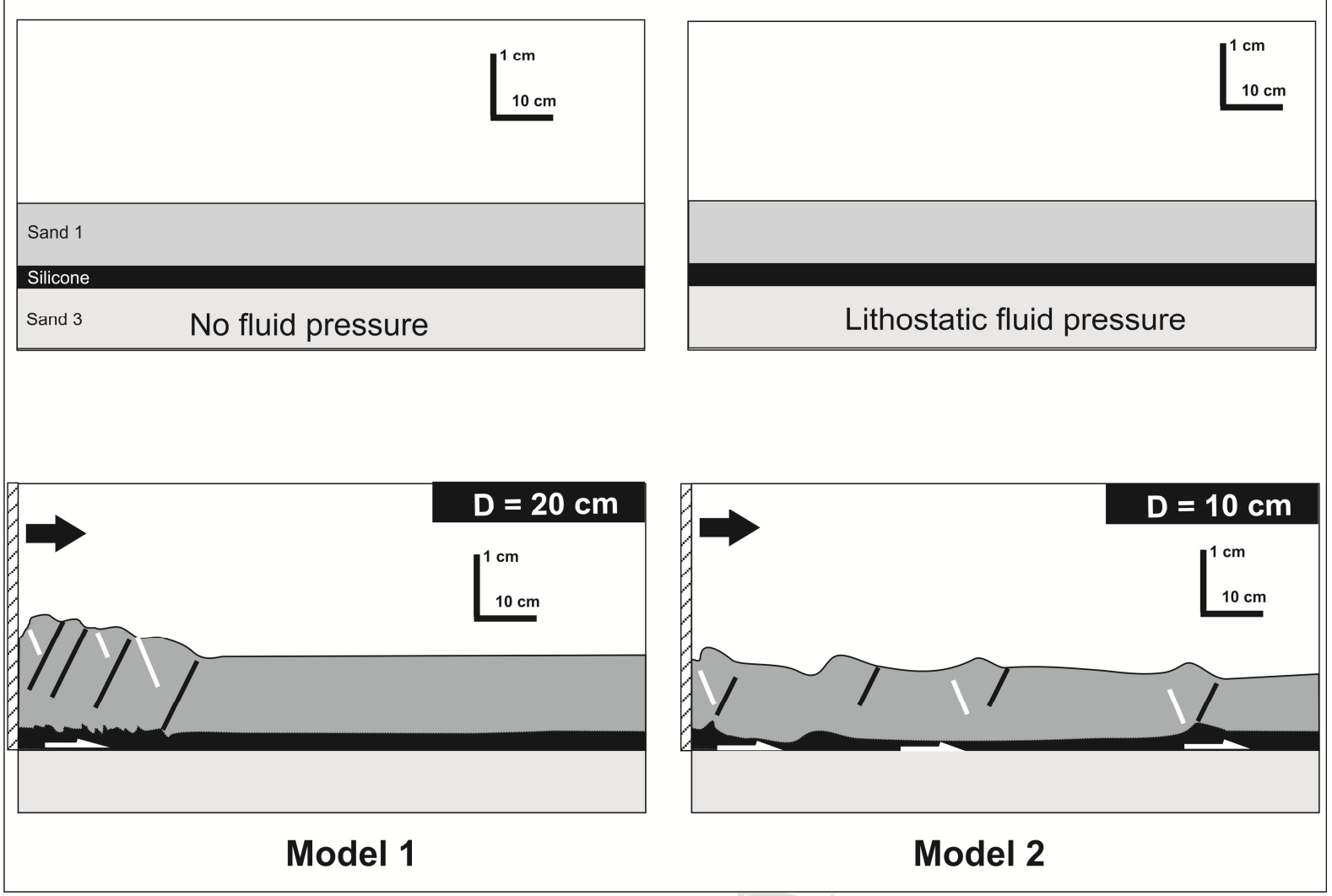

Model 1

Model 2 
* The following figure(s)/table(s) is/are missing: 1.we have received citation for table 6 in manuscript but corresponding table is missing. kindly check and advise. 2.[figure caption missing] we have received figure $21 \mathrm{a}, \mathrm{c}$ but the corresponding caption is not supplied. kindly check and advise.

\section{1. we have received citation for table 6 in manuscript but corresponding table is missing. kindly check and advise.}

Figure 8. Apparatus (after Rodrigues et al., 2009). Longitudinal section (A) and threedimensional view (B) show plexiglass box for housing models (1), flow diffuser containing sand (2), metallic mesh (3), reservoir for compressed air (4), pressure regulator (5) and tilting table beneath model (6). Pressure probes (narrow aluminium tubes) protrude horizontally through sidewalls of box (7). Their outer ends connect to U-tubes, containing water (8).

The tilting table (6) is not a reference to a Table of data. Instead, in Figure 8 (B, right), it refers to a three-dimensional view, where there is a physically tilting table, beneath the model.

\section{2. [figure caption missing] we have received figure $21 \mathrm{a}, \mathrm{c}$ but the corresponding caption is not supplied. kindly check and advise.}

Figure 21. Model 4. Photographs (top) and line drawing (bottom) show a single section through 3 basal layers and parallel to shortening direction. Basal layers include lowermost one of silicone, intermediate one of sand and uppermost one of silicone (with some sand sticking to its upper surface). Both silicone layers are in strips of alternating colours (red or transparent), which have visible boundaries (T1 to T4 for lower layer, T'1 to T'4 for upper layer). Line drawing of section (bottom) shows final positions of all these boundaries. Enlargement of photograph (B) shows details of compressional structures (folds and faults) within intermediate layer of sand. Final displacement of piston (right) was $24.5 \mathrm{~cm}$.

Figure 21. Model 4. Photographs (A, top) and line drawing (C, bottom) show a single section through 3 basal layers and parallel to shortening direction. Complete photograph (A) shows that basal layers include lowermost one of silicone, intermediate one of sand and uppermost one of silicone (with some sand sticking to its upper surface). Enlargement (B) of central part of photograph shows details of compressional structures (folds and faults) within intermediate layer of sand. Line drawing of section (C) shows final positions of all these boundaries. Final displacement of piston $(24.5 \mathrm{~cm})$ is also visible $(\mathrm{C}$, right). Both silicone layers are in strips of alternating colours (red or transparent), which have visible boundaries (T1 to T4 for lower layer, T' 1 to T' 4 for upper layer). 